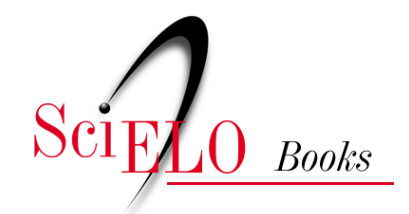

EDUFU

\title{
Os índios da Farinha Podre
}

\author{
Luís Augusto Bustamante Lourenço
}

\section{SciELO Books / SciELO Livros / SciELO Libros}

LOURENÇO, L.A.B. Os índios da Farinha Podre. In: A oeste das minas: escravos, índios e homens livres numa fronteira oitocentista Triângulo Mineiro (1750-1861) [online]. Uberlândia: EDUFU, 2005, pp. 41-93. ISBN 978-85-7078-516-9. https://doi.org/10.7476/9788570785169.0004.

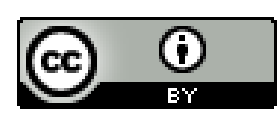

All the contents of this work, except where otherwise noted, is licensed under a Creative Commons Attribution 4.0 International license.

Todo o conteúdo deste trabalho, exceto quando houver ressalva, é publicado sob a licença Creative Commons Atribição $\underline{4.0}$.

Todo el contenido de esta obra, excepto donde se indique lo contrario, está bajo licencia de la licencia $\underline{\text { Creative Commons }}$ Reconocimento 4.0. 


\section{2 | Os índios da Farinha Podre}

\section{O ambiente do Cerrado e sua primeira ocupação}

Conceber a história e o espaço como dimensões formadas por cadeias de eventos complexos significa, antes de tudo, rejeitar qualquer interpretação determinista dos fatos históricos e geográficos: o determinismo geográfico, que desistoriciza a realidade, e o determinismo histórico, que vê a história dos homens como a única possível, e o homem como o seu demiurgo. Existe uma história do ambiente, de tempos longos, da qual o homem não é o único partícipe e, muitas vezes, sequer o principal.

Nesse sentido, a compreensão da história humana passa pelo conhecimento do ambiente sobre o qual ela se desenrola. Ambiente que não pode ser visto como um palco inerte, que apenas cria o cenário para a trama dos homens. Formado pelas heranças da natureza e das ações humanas do passado, ele é parte ativa dessa trama.

Assim, neste trabalho, tornou-se fundamental conhecer as possibilidades oferecidas às sociedades do passado pelo ambiente do Cerrado. Como já foi dito linhas atrás, estudaremos a transição — radical e violenta — ocorrida entre duas espacialidades, nos séculos XVIII e XIX: o Cerrado indígena, que consistia num espaço milenar, ocupado por uma economia horticultora e aldeã, complementada por atividades de caça e coleta; e o Cerrado geralista, espaço de uma sociedade que se fundamentava numa economia agrícola e pecuarista, que, apesar de ter incorporado um grande número de técnicas indígenas, organizava o trabalho humano e utilizava os recursos do Cerrado de forma inteiramente diferente da sociedade anterior e que, por isso, a destruiu.

Esse, sabemos nós, é apenas um capítulo de uma história maior que ainda não se encerrou: a expansão econômica, cultural, demográfica, tecnológica, biológica e microbiológica da Europa sobre as sociedades e ambientes précolombianos. Esse confronto teve desfechos distintos, por ter-se tratado não 
de um, mas de vários confrontos diferentes, já que muitas eram as sociedades do Novo Mundo que enfrentaram os europeus. Em todos eles, sem dúvida, o resultado não foi outro senão o genocídio e a destruição dos povos americanos. Porém, diferenças importantes existiram, por exemplo, entre a América Andina e a Mesoamérica de um lado, e entre o Brasil e os Estados Unidos de outro.

No primeiro caso, como no México asteca ou nos Andes incaicos, os conquistadores espanhóis encontraram sociedades estratificadas e sedentárias, organizadas sobre uma base camponesa, com elites urbanas vivendo do excedente extraído de seu trabalho. Na conquista, essas classes dominantes nativas foram eliminadas, e o aparato de dominação espanhol tomou o seu lugar, preservando as populações camponesas e adaptando, mas não eliminando, as velhas relações de produção pré-colombianas. Sobreviveram as sociedades camponesas no sul do México, Guatemala, Honduras, Peru, Equador e Bolívia, inclusive com suas línguas e relações de parentesco.

A existência de um campesinato pré-colombiano, que praticava agricultura com terraceamento, sistemas de irrigação, e que contava com densidades demográficas significativas, explica por que os conquistadores preferiram o domínio ao extermínio. Forjou-se, nesse caso, uma sociedade colonial singular, na qual, para Cardoso e Brignoli:

As comunidades indígenas constituíam o eixo principal do sistema de trabalho que estiveram em ação entre 1550 e o fim do período colonial. Sua origem está claramente estabelecida: trata-se das congregações e reduções ordenadas pela Coroa na Segunda metade do século XVI. O sistema associou, porém, a um plano urbano e administrativo tipicamente espanhol, centrado na Igreja e no cabildo, concepções de propriedade e organização do trabalho coletivo de origem pré-hispânica (carpulli, aylu, minca, aymi) e de ascendência hispânica (ejidos, terras de légua, próprios de aldeia etc.). O resultado foi uma rede de comunidades fortemente integradas entre si e que proporcionaram um importante fluxo tributário para a Coroa, e prestações de trabalho para os proprietários de minas e para os fazendeiros. (1984, p. 86-87).

A partir dessas constatações, relativas à América Espanhola, podemos formular a seguinte pergunta: por que, no Brasil, o contato entre europeus e índios resultou no extermínio destes? Na verdade, não houve extermínio físico 
total dos índios: grande parte da população indígena brasileira miscigenou-se com os brancos e africanos. As sociedades indígenas é que desapareceram, e por uma razão: tratava-se de sociedades comunais, que viviam em pequenos bandos dispersos, esporadicamente se reuniam em grupos maiores e proviam suas existências pela horticultura, caça e coleta. Tais formas econômicas e sociais eram incompatíveis com os interesses coloniais.

Os caiapós meridionais, nome que designava grupos do Tronco MacroJê lingüisticamente aparentados, habitavam o Triângulo Mineiro e mais uma vasta área correspondente aos atuais estados de Minas Gerais, Goiás, São Paulo, Mato Grosso do Sul e Mato Grosso, à época da chegada dos primeiros colonizadores luso-brasileiros (Turner, 1992). Esta região é parte da área do Sistema Biogeográfico do Cerrado, que domina grande parte do Brasil Central, e áreas menores, em alguns países vizinhos (figura 1).

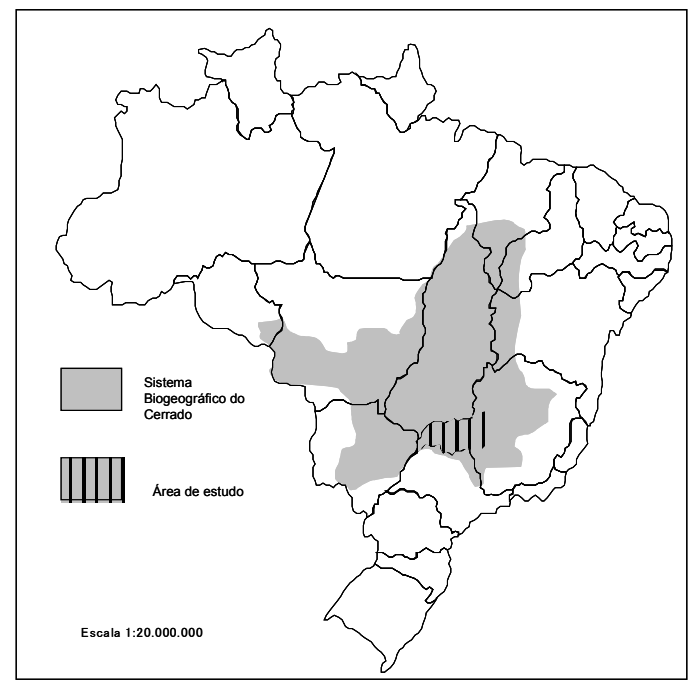

Figura 1: O Sistema Biogeográfico do Cerrado e a área de estudo Fonte: Ferreira (1998)

A presença desses povos na região em estudo já era muito antiga quando da chegada dos colonizadores: os indícios arqueológicos dos primeiros povos horticultores e ceramistas remontam a 1.000 anos, aproximadamente, conhecidos como Tradição Aratu-Sapucaí (Barbosa; Shmiz, 1998). Esses 
agricultores construíam aldeias nas matas-galeria, na margem dos cursos d'água, praticavam agricultura fundamentada no milho, e desconheciam a mandioca.

A área de distribuição da Tradição Aratu-Sapucaí (Oeste Mineiro e Sul Goiano) correspondia quase exatamente à região dos caiapós meridionais. Inúmeras outras coincidências entre os achados arqueológicos e os registros históricos sobre os caiapós levam os especialistas à suposição de que existe uma continuidade cultural entre aquela tradição e esse povo indígena do período colonial (BARBOSA; SHMIZ, 1998). Não foram, contudo, os primeiros povoadores da região, pois uma outra cultura ainda mais antiga, a Tradição Itaparica, formada por caçadores e coletores exclusivos, antecedeu a Aratu-Sapucaí, e remontava ao final do Pleistoceno (Dillehay, 2000). Nossa região em estudo, desse modo, vem sendo habitada há pelo menos 12.000 anos.

Os caiapós meridionais, hoje extintos, alternavam as atividades de horticultura com a caça e a coleta. Quase todos os povos pré-cabralianos cultivavam uma lista de espécies vegetais, que consistia basicamente no milho, na mandioca brava, no aipim ou mandioca mansa, em duas espécies de feijão, na abóbora e na batata-doce (GALVÃo, 1979). Havia, contudo, algumas espécies preferencialmente cultivadas em algumas áreas culturais, como o milho na região em estudo e em toda a área dos caiapós. O antropólogo Roberto Galvão (1979) dividiu o espaço pré-colonial brasileiro em uma imensa área milheira e outra mandioqueira. Tal divisão tem importância para o entendimento das técnicas de cultivo e beneficiamento incorporadas pelos colonizadores, quando do contato com os povos nativos (figura 2).

A abertura das roças caiapós em nada diferia do usual, dentre as populações indígenas. Começava pela derrubada de um trecho de mata, utilizando como instrumento o machado de basalto, granito ou diabásio. Em seguida, ocorria a queimada e o plantio nas primeiras chuvas de inverno, usando como instrumento o pau de cavar (GALVÃo, 1979) ou chuço (HolANDA, 1994), bastão de um metro e meio de comprimento, com ponta endurecida a fogo. Os cultivos repetiam-se no mesmo lugar, por dois ou três anos, após o quê a área era abandonada e novo trecho da mata era utilizado.

Eram essas as práticas dos caiapós meridionais em nossa área de estudo, à época da chegada dos primeiros colonos luso-brasileiros. O primeiro vigário da freguesia de Uberaba, Antônio José da Silva, ao narrar a entrada pioneira de geralistas na região, em 1810, relatou que os sertanistas evitavam o encontro 
com os caiapós, "cuja existência se conhecia, ou pelas queimadas, que fazia, de campos, ou pelos seus ranchos encontrados aqui e ali” (1970, p. 07).

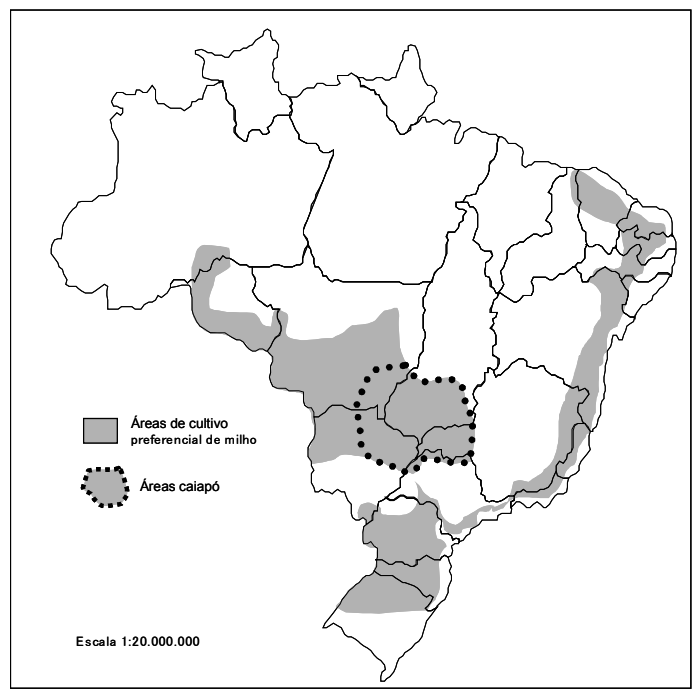

Figura 2: áreas de cultivos indígenas preferenciais e área cultural caiapó meridional antes da conquista européia.

Fonte: Galvão (1979).

À medida que as áreas de cultivo iam-se distanciando da aldeia, surgiam os centros, para onde as famílias se transferiam e transportavam o instrumental de beneficiamento. Com o passar do tempo, tais centros podiam transformarse em novas aldeias (GALVÃo, 1979). Desse modo, o sistema itinerante da agricultura indígena impunha um caráter seminômade às aldeias. Ao mesmo tempo, era exatamente essa forma de vida que garantia a sustentabilidade da economia indígena no ambiente do Cerrado.

Boserup (1987) criou um esquema de classificação dos sistemas agrícolas tradicionais, baseado na intensidade do uso da terra. Os cultivos de pousioflorestal consistem em clareiras abertas na floresta virgem, nas quais a terra é cultivada por dois anos. Após esse período de cultivo, é deixada em repouso por 20 a 25 anos, tempo necessário à recolonização completa da cobertura vegetal original e à reconstituição do solo de floresta. Segundo o modelo da autora, aumentos da densidade demográfica obrigam o encurtamento do pousio 
e a utilização de sistemas cada vez mais intensivos.

No caso da horticultura indígena da região em estudo, parece claro que se tratava de um cultivo de pousio florestal típico, compatível com as baixas densidades demográficas dos povos ameríndios na região do Cerrado. Tal sistema de agricultura itinerante em ambientes tropicais pode sustentar-se indefinidamente, sem grandes impactos ambientais. Usando a terminologia de Odum (1988), o clímax ecológico regional não se alteraria com as práticas dessas sociedades, já que a relação produção/respiração total do ecossistema regional se manteria inalterada, embora pudessem alterar, ainda que transitoriamente, essa relação em ecossistemas locais.

É provável, inclusive, que algumas fisionomias vegetais, encontradas nas matas e nos cerrados pelos colonizadores luso-brasileiros e tidas como "naturais", sejam estágios de desenvolvimento (ou comunidades transitórias, no dizer de Odum) de sucessões ecológicas iniciadas sobre campos de cultivo indígenas abandonados. Pierre Monbeig (1998) refere-se, por exemplo, à "quiçaça”, ou campo cerrado, encontrada no Oeste Paulista por botânicos do início do século XX, em áreas povoadas por índios. $\mathrm{Na}$ verdade, tal formação corresponderia ao primeiro estágio na sucessão ecológica sobre solos por eles cultivados, do Bauru Superior, evoluindo, em algumas dezenas de anos, para o cerrado strictu sensu.

Os caiapós meridionais abriam suas roças de milho e, uma vez plantadas, dispersavam-se em pequenos bandos para as atividades de caça e coleta, voltando a concentrar-se na época da colheita. O plantio era feito pelas mulheres, em sistema de mutirão, quando algumas abriam as covas e outras jogavam nelas três ou quatro grãos. Uma vez maduras as espigas, as mulheres percorriam novamente a roça para quebrá-las, para proteger a colheita das chuvas. As espigas eram recolhidas aos poucos nos paióis - pequenas construções de duas águas, cobertas de sapé e elevadas do chão. Após a colheita, a área era normalmente usada para o plantio do feijão, utilizando-se a haste do milho como proteção e suporte para as ramas (GALVÃo, 1979). Como veremos no capítulo 4, tais técnicas de preparo da terra, plantio e beneficiamento de alimentos foram quase integralmente adotadas pelos colonizadores luso-brasileiros, em nossa região de estudo, com poucas modificações.

Os sistemas de propriedade, organização e divisão social do trabalho dos ameríndios brasileiros, diversamente do que acontecia na América Espanhola, eram incompatíveis com as formas de produção da sociedade colonial. Daí, 
conforme vimos, o desaparecimento daquelas sociedades. Suas técnicas, contudo, resultado de um milenar processo de aperfeiçoamento frente às características ecológicas de ambientes tropicais, sobreviveram, incorporadas pelo colonizador.

\section{Sertanismo e caboclização}

A sociedade colonial prescindia das sociedades horticultoras, caçadoras e coletoras indígenas, e por isso foram destruídas. Entretanto, não prescindia da força de trabalho indígena, daí sua escravização. A escravidão indígena teve grande importância em todo o período colonial, principalmente na Amazônia, até o século XIX, e em São Paulo, até o início do século XVIII (GORENDER, 1988).

Quando o objetivo dos grupos coloniais era destruir as sociedades indígenas, para que o espaço por elas ocupado pudesse ser colonizado, recorria-se ao sertanismo de extermínio, isto é, expedições armadas destinadas a aniquilar fisicamente os núcleos indígenas. Elas se fizeram presentes em toda a história da ocupação do território brasileiro, e ainda existem nos dias atuais, consistindo no primeiro passo na ocupação de uma região de fronteira. No Oeste Paulista, no período compreendido entre 1890 e 1900 , por exemplo, ocorriam as dadas — expedições de extermínio contra os caingangues organizadas pelos bugreiros, sertanistas mercenários especializados no extermínio indígena — que alugavam seus serviços em zonas pioneiras desde o Sul do Brasil (MonBEIG, 1998). No final dos anos 1980, expedições de caça e extermínio de índios Uruéu-wau-wau e Arara foram realizadas em Rondônia e no Pará, respectivamente (MARTINs, 1998).

No período colonial, no entanto, eram freqüentes as expedições destinadas não só a aniquilar os núcleos nativos, mas também a escravizar os índios. Chamaremos essa prática de sertanismo de apresamento. As expedições sertanistas foram, na maioria dos casos, o primeiro contato que os povos indígenas tiveram com a sociedade colonial.

Outro desfecho, que se pode seguir ao contato entre a sociedade nacional e os povos indígenas, é o da aculturação, que resulta de uma acomodação entre indígenas e roceiros. Nesse caso, estabelece-se uma coexistência, na qual o indígena, aos poucos, abre mão das práticas de caça e coleta e da agricultura tradicional, e se sedentariza, absorvendo de forma crescente elementos culturais dos caboclos, 
até que seu modo de vida se torne indistinguível destes. A língua e a religião são esquecidas e a identidade indígena desaparece, diluída na sociedade sertaneja circundante. Chamaremos caboclização esse processo de aculturação. Galvão cita o exemplo dos Tenetehara, do rio Pindaré (MA), onde o contato com grupos caboclos que vivem da coleta comercial do babaçu permitiu relações econômicas cada vez mais intensas entre índios e a economia local. Segundo o autor:

Embora o grupo mantenha sua unidade tribal e possa ser distinguido da população cabocla por uma configuração cultural diferente, são evidentes os sinais de desgaste da cultura tradicional e os de substituição de valores tribais por outros, brasileiros, resultantes do impacto de trezentos anos de convívio geralmente pacífico com nossa sociedade rural. Concluímos que não demoraria talvez mais do que uma ou duas gerações para que os Tenetehara se transformassem em caboclos (GALVÃo, 1979, p. 130-131).

No Triângulo Mineiro, houve tanto o extermínio das populações caiapós, quanto sua caboclização. A região em estudo passou, todavia, por uma experiência histórica pouco comum. Aqui, foram assentadas populações indígenas vindas de outras regiões, como de Goiás (acroás, chacriabás e tapirapés) e do Mato Grosso (bororos e parecis), em aldeamentos criados pelo colonizador. Estes consistiram, na verdade, na primeira forma de ocupação colonial da região, que começou em 1730, quando a região em estudo, e de resto todos os atuais territórios dos estados de Goiás, Tocantins, Mato Grosso e Mato Grosso do Sul ainda eram parte da capitania de São Paulo. Para que possamos entender o papel dos aldeamentos na ocupação colonial do Triângulo Mineiro, é necessário recapitular como essa forma paulista de exploração da força de trabalho indígena irradiou-se até lá.

\section{Legislação, aldeamentos e a escravidão indígena na capitania de São Paulo}

No Triângulo Mineiro, a primeira forma de ocupação colonial consistiu, paradoxalmente, em núcleos de população indígena instituídos pelo colonizador: os aldeamentos. Estes foram uma criação colonial que teve sua primeira aparição no Planalto do Piratininga, de 1553 em diante. Os jesuítas, liderados pelo padre José de Anchieta, foram criadores do sistema em sua versão luso-brasileira. 
Nestes núcleos, a população ameríndia nativa era sedentarizada, de forma compulsória ou cooptada pela catequese, e a partir de então era tutelada pelo colonizador. Para tanto, a Companhia de Jesus recebeu da Coroa concessões de terra em torno da vila de São Paulo, onde instalou capelas, povoados e fazendas, dando forma aos aldeamentos.

Houve árdua disputa entre colonos e jesuítas pelo controle dos indígenas nos primeiros anos da colonização de São Paulo (1553-1640). Os fazendeiros paulistas, sem contar com gêneros tropicais que pudessem ter valor na exportação transatlântica — e por isso sem recursos para utilizar o tráfico negreiro como fonte de força de trabalho --, recorreram de início à escravidão dos índios do próprio Planalto. Com o escasseamento destes, passaram a organizar expedições de apresamento em zonas cada vez mais remotas, no interior do continente. Parte dos índios descidos do sertão era mantida na escravaria particular do sertanista apresador, e parte era entregue aos jesuítas, que os reduzia nas missões. Nelas, os colonos podiam também usar sua força de trabalho, desde que pagassem seu jornal aos padres da Companhia (Monteiro, 1994).

Em 1611, a Ley sobre a Liberdade do Gentio da Terra, e a Guerra que se lhe Pode Faz̧er estabeleceu as bases que, desde então, passaram a justificar as expedições de apresamento. Embora declarasse livres todos os índios do Brasil, aceitava a escravidão daqueles capturados em guerras justas. As pressões exercidas pelos jesuítas sobre os colonos e a ambigüidade da legislação conformaram, no século XVII, a peculiar escravidão indígena paulista, que negava a si própria nos inventários e noutros documentos da capitania de São Paulo, mas, na prática, reproduzia-se da mesma forma que a escravidão de africanos em outras regiões do Brasil (Monteiro, 1994).

Nos aldeamentos criados pelos jesuítas em torno da vila de São Paulo (Pinheiros, Guarulhos e São Miguel em 1560, Carapicuíba, Escada, Barueri, Itapecerica e Itaquaquecetuba no início do século XVII) também existia trabalho compulsório, de cujo excedente os padres se apropriavam, sendo o produto restante dividido entre os indígenas.

As Cartas Régias de 26 de janeiro e 19 de fevereiro de 1696 passaram a disciplinar uma prática que, desde o início daquele século, já ocorria em São Paulo: a administração (Petrone, 1995). Consistia no uso da força de trabalho dos indígenas dos aldeamentos, pelos fazendeiros ou sob ordens da Coroa, 
mediante pagamento, na verdade, irrisório, entregue aos seus diretores. Muitas vezes, esse pagamento não ocorria, e os índios de um determinado aldeamento poderiam manter-se como escravos de um proprietário até sua morte. Também era comum que sertanistas solicitassem aos jesuítas ou à Câmara de São Paulo, no caso das aldeias do Padroado Real, um certo número de índios para organizar uma armação (expedição sertanista). Jacob Gorender (1988) chama esse conjunto de práticas de escravidão incompleta, e Pasquale Petrone (1995), de escravidão disfarçada. Ambos perceberam sua semelhança com o sistema de encomiendas usado nas colônias espanholas da América.

Tanto nas encomiendas espanholas quanto na administração luso-brasileira, as reduções funcionavam como reservas de força de trabalho para a coletividade de colonos, os quais solicitavam índios ao encomiendero ou administrador, geralmente, um funcionário ou uma ordem religiosa. A estes estavam subordinados os caciques ou principais — indígenas na posição de chefe — , cuja tarefa era selecionar os índios que seriam cedidos pelo aldeamento (Petrone, 1995).

A diferença essencial entre as duas instituições decorria da própria natureza dos sistemas coloniais português e espanhol, como visto linhas atrás. Enquanto no Brasil houve a completa destruição das sociedades précabralianas e do seu modo de produção coletivista, na América Espanhola as comunidades camponesas pré-colombianas foram mantidas, inclusive com parte de suas instituições políticas, como o cacicato. Assim, nos aldeamentos hispano-americanos, houve uma superposição do aparato colonial sobre as comunidades camponesas indígenas. $\mathrm{Na}$ América luso-brasileira, no entanto, os aldeamentos foram criações novas, comunidades rurais que surgiam pelas mãos do colonizador, com a redução dos índios apresados em núcleos sedentários. As sociedades indígenas tradicionais eram destruídas no processo, e a cultura e as relações de trabalho da sociedade colonial eram impostas aos índios (figura 3).

Em 1727, o governador da capitania de São Paulo criou um regimento para o sistema de administração, no qual os aldeamentos ficariam sob as ordens de um Protetor dos Índios (um jesuíta) e de um procurador secular, subordinado ao primeiro (PETRONE, 1995). Nesse período, os paulistas criaram novos núcleos coloniais em torno de jazidas auríferas recém-descobertas, como Minas Gerais (1690), Cuiabá (1718) e Goiás (1725), onde repetiriam a experiência dos aldeamentos já praticada no Planalto do Piratininga. 


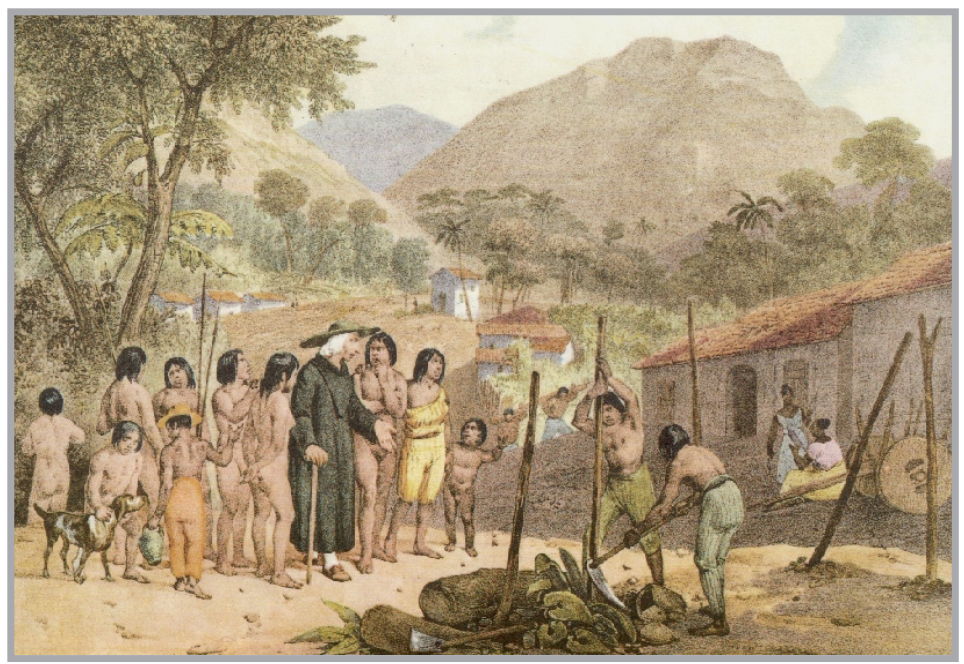

Figura 3: Rugendas: Aldeia de Tapuias Fonte: Rugendas (1998)

Os aldeamentos goianos interessam-nos mais de perto, pois o Triângulo Mineiro foi parte do território de Goiás até 1816. Durante os mais de sessenta anos que essa região pertenceu àquela capitania, os aldeamentos foram praticamente a única experiência colonizadora ali empreendida pelo governo goiano. É dela que trataremos a seguir.

\section{A Estrada dos Goiases e os aldeamentos do Sertão da Farinha Podre}

Entre 1722 e 1725, sertanistas paulistas, liderados por Bartolomeu Bueno da Silva (o Anhanguera) e João Leite da Silva Ortiz, descobriram as Minas dos Goiases, nas cabeceiras do rio Vermelho, afluente da bacia do Araguaia. Em pouco tempo, paulistas afluíram para lá, criando arraiais em torno das lavras, tais como Santa Cruz, Santa Luzia, ${ }^{1}$ Meia Ponte ${ }^{2}$ e Jaraguá, e uma vila planejada, Vila Boa ${ }^{3}$ (Palacin; Moraes, 1994).

\footnotetext{
Hoje Luziânia

Hoje Pirenópolis

3 Hoje Cidade de Goiás
} 
Entre o território das minas goianas e São Paulo, foi aberto um caminho régio, em 1730, que correspondia aproximadamente ao trajeto do Anhanguera (Palacin; Garcia; Amado, 1995), cujos descendentes, até o início do século XIX, mantiveram o usufruto do pedágio (SAint Hilaire, 1975). Uma Carta Régia, datada de 1730, estabelecia aquele como o único caminho para as minas de Goiás, e previa penas para quem usasse desvios (Palacin; Garcia; Amado, 1995).

Esse caminho, disposto aproximadamente na direção sul-sudeste nor-noroeste, atravessava uma área de chapadões, cortados por vales fluviais, cujos cursos d'água são orientados no sentido sudeste-noroeste. Foi possível reconstituir, com certa aproximação, o traçado do caminho, graças aos relatos de viagem de Saint Hilaire (1975 a; 1976), Eschwege (1996) e Luís D’Alincourt (1975), cotejados com cartas topográficas (figura 4).

O trecho que chegava até Mogi-Guaçu já era bastante conhecido e transitado pelos sertanistas, desde o século XVII (Palacin; Garcia; Amado, 1995). Desse ponto em diante, percebe-se, pelo traçado, a intenção de cruzar-se os rios "mais próximos às suas nascentes (...), [seguindo] próximo às primeiras elevações da banda ocidental da Serra da Mantiqueira, evitando as regiões mais alagadiças, de difícil travessia e sujeitas às febres palustres" (BACELAR; BRIOSCHI, 1999, p. 46).

No trecho paulista, a estrada estava disposta no sentido nor-noroeste. Após a travessia do rio Grande, já em Goiás, no território que hoje corresponde ao Triângulo Mineiro, seguia pelo sentido norte, num notável alinhamento com o meridiano $47^{\circ} 58^{\prime} \mathrm{O}$, para novamente assumir o sentido nor-noroeste após a travessia do rio Paranaíba.

No trecho triangulino, a estrada passava pela crista dos chapadões, por ser esse o espaço mais transitável na mesopotâmia entre os rios Grande e Paranaíba. Estendia-se por $195 \mathrm{~km}$ de grande regularidade topográfica, sobre planuras cobertas por campo sujo e campo cerrado, cujas altitudes variavam de 915 a $950 \mathrm{~m}$, exceto nos vales fluviais. Nestes, apenas três cursos d'água eram de difícil travessia: o rio Grande, cujo profundo vale, então recoberto por densa floresta, chega a $550 \mathrm{~m}$ de altitude; o rio das Velhas ${ }^{4}$ e o rio Paranaíba. Os rios Uberaba Falsa, ${ }^{5}$ Tejuco e Uberaba Legítima ${ }^{6}$ eram

\footnotetext{
Hoje rio Araguari

Hoje rio Uberaba

6 Hoje rio Uberabinha
} 


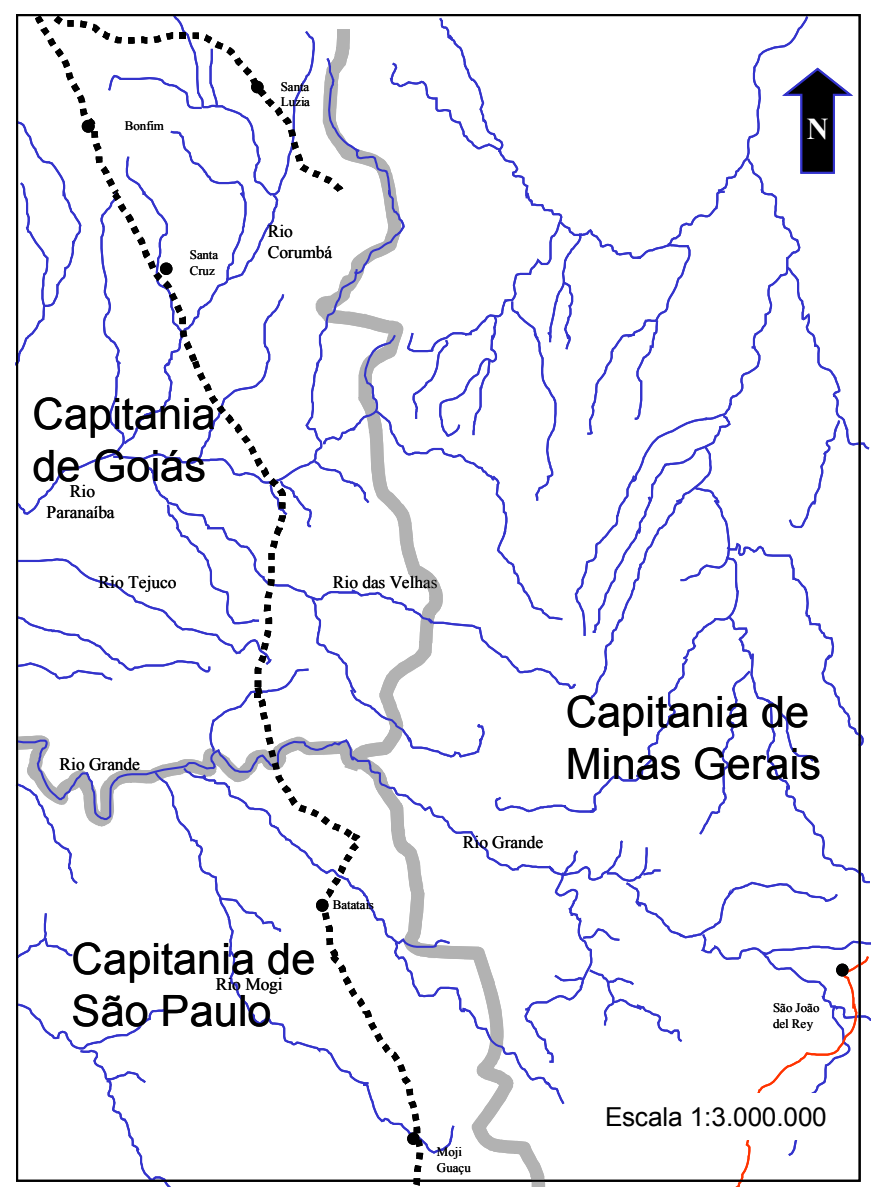

Figura 4: estrada do Anhanguera ou dos Goiases (1736).

Fonte: D’Alincourt (1975); Saint Hilaire (1975); Eschwege (1996) ; IBGE (1972).

cruzados próximos de suas cabeceiras, em pontos facilmente vadeáveis durante a seca (SAint Hilaire, 1975).

No início da colonização de Goiás, incursões caiapós ameaçaram a estabilidade dos arraiais do ouro e, principalmente, o tráfego pela estrada do Anhanguera. A resistência caiapó já era conhecida dos paulistas desde as primeiras bandeiras em Goiás. É provável que os revezes dos colonizadores tenham sido o fator responsável pela absoluta ausência de povoados e fazendas 
em toda a faixa de terras compreendida na bacia do baixo Paranaíba e baixo rio Grande (atual sul de Goiás, noroeste de São Paulo, pontal do Triângulo Mineiro e leste do Mato Grosso do Sul), até a época em que Aires de Casal (1976) escreveu sua Corografia Brasílica, em 1817:

É a menos conhecida [região da província de Goiás], não havendo nela estabelecimento algum de cristãos. Os caiapós, que a dominam (repartidos ainda, segundo dizem, em várias tribos), têm sido fatais por vezes aos comboios cuiabanos, e invadido a parte setentrional da província de São Paulo, onde causaram a deserção de muitos estabelecimentos. (CASAL, 1976, p. 151).

Casal apropriadamente chamou essa região de Caiapônia, pois tratava-se de uma parte do interior da Colônia, onde a resistência indígena impediu, por muito tempo, que se instaurassem os poderes do Estado Colonial. Até o início do século XVIII, correspondia ao território do julgado goiano de Santa Cruz. O arraial de Santa Cruz, sede daquele território, situava-se ao longo do trajeto da Estrada dos Goiases. Saint Hilaire refere-se a ele como tendo

[...] 40 léguas aproximadamente, de norte ao sul, indo desde o Rio Jurubatuba até o Paranaíba, na fronteira da província [de Goiás]. Ainda não tem limites fixos a oeste, onde existe uma imensa região desabitada e desconhecida. A paróquia inteira de Santa Cruz não conta com mais de 3.000 fiéis. (1975 a, p. 118).

De fato, a colonização do Sudoeste Goiano por mineiros geralistas só começou depois de 1830, após o aldeamento e o extermínio dos caiapós, e com a abertura de uma Estrada Real pelo engenheiro militar Cunha Matos, nos anos 1820 (FERREIRA, 1958).

Em Carta Régia de 1749, destinada a D. Marcos Mendonça, governador da capitania de Goiás, a Coroa portuguesa decidiu pela guerra aos caiapós, "que não cessa de infestar com as mais cruéis hostilidades o caminho de São Paulo para os Goiás, e até as povoações daquelas Minas" (PALACIN; Garcia; AmADo, 1995, p. 69). Um ano antes, em 1748, os caiapós haviam dizimado os garimpeiros de um núcleo aurífero, nas cabeceiras do rio das Abelhas, ${ }^{7}$ no

\footnotetext{
Hoje rio Araguari
} 
mesmo lugar onde, alguns anos depois, surgiria o arraial do Desemboque (VASCONCELOS, 1999). Impunha-se uma solução militar contra os caiapós da região dos rios Paranaíba e Grande, para resguardar a segurança do tráfego na Estrada dos Goiases. Para isso, o governo da capitania de Goiás contratou os serviços do sertanista paulista Antônio Pires de Campos, o moço.

Ainda no século XVIII, parecia ser comum a contratação de paulistas pelo Estado Colonial, para a prática do sertanismo de extermínio, com o intuito de desinfestar de índios e quilombolas as áreas de fronteira. Fórmula semelhante já havia sido usada, por exemplo, nas expedições contratadas pelo governador de Pernambuco e comandadas por Domingos Jorge Velho contra o Quilombo de Palmares, em 1694 (LARA, 1996).

Em Minas, tal prática também era freqüente: uma Ordem Régia, de 1745, dirigida ao governador Gomes Freire de Andrade, propunha a vinda de duzentos casais de índios paulistas para que se estabelecesse uma rede de aldeamentos nas comarcas do Oeste Mineiro, de onde partiriam expedições de extermínio aos quilombos do alto São Francisco (VAsconcelos, 1999). Nas primeiras campanhas da guerra contra os quilombos do Oeste Mineiro, de 1745 a 1749, o paulista Antônio João de Oliveira liderou 400 índios bororos, contratados pelo governador interino de Minas, José Antônio Freire de Andrade (Mello E Souza, 1999).

Essa foi também a solução adotada pela câmara de Vila Boa de Goiás para acabar com os ataques dos caiapós na estrada para São Paulo. De acordo com carta de D. Marcos de Noronha, Conde dos Arcos, datada de 1749, depois de repetidas solicitações feitas pelo governador de São Paulo, a autorização para o início de ações contra os caiapós foi finalmente concedida em 1746 (Palacin; Garcia; Amado, 1995). A câmara de Vila Boa contratou, às expensas dos fazendeiros e mineradores goianos, o paulista (estabelecido no Cuiabá) Antônio Pires de Campos, o moço, filho do legendário Antônio Pires de Campos, o velho, pioneiro da navegação monçoneira e descobridor das lavras cuiabanas (Holanda, 1995). Tinha a seu serviço índios bororos e parecis, contactados durante a colonização cuiabana e aldeados nos arredores da vila do Cuiabá.

Pires de Campos partiu daquela vila acompanhado de 500 índios, iniciando uma campanha de extermínio e apresamento dos caiapós, que duraria até 1750. Com grande violência, repeliu os caiapós em todo o trecho da estrada entre os rios Paranaíba e Grande, na região que, do final do século XVIII em diante, 
passaria a ser conhecida por Sertão da Farinha Podre. Em seguida, obedecendo ainda à determinação do governador paulista, fundou alguns aldeamentos ao longo do trecho, onde distribuiu seus índios bororos, que doravante se tornariam responsáveis pela defesa do trânsito na estrada (PALACIN; GARCIA; AmAdo, 1995).

O número exato desses aldeamentos originais é controverso, mas o padre Luiz Antônio Silva e Souza, em 1812, recolheu da tradição oral o número de três, situados próximos às passagens dos rios mais caudalosos: as aldeias do Rio das Pedras, ${ }^{8}$ Santana ${ }^{9}$ e Lanhoso ${ }^{10}$ (Palacin; Garcia; Amado, 1995). Já Aires de Casal (1976) escreveu que a aldeia de Lanhoso surgiu depois, em 1775, quando os índios bororos da aldeia de Santana foram transferidos para as proximidades do rio Grande, para dar lugar aos chacriabás trazidos pelo governo goiano. Eschwege (1996) visitou nove aldeamentos no trajeto da estrada, em 1816. A maioria deles, como sugeriremos adiante, deve ter nascido de divisões da população dos três originais. Saint Hilaire relatou que Pires de Campos fundara somente Rio das Pedras e Santana. As aldeias de Estiva, Piçarrão e Boa Vista surgiram, segundo o cronista, de desmembramentos da população do Rio das Pedras.

Pela descrição que aqueles viajantes deram desses núcleos, só Rio das Pedras, Santana e Piçarrão mereceriam o nome de aldeamentos, pois eram os únicos que contavam com capelas. A presença do templo religioso era sinal da oficialidade de sua fundação, de que o núcleo havia sido reconhecido pelas autoridades religiosas. Os demais povoados eram destacamentos dos núcleos originais, resultado de um processo de dispersão centrífuga da população aldeada, cujas causas analisaremos adiante.

Pires de Campos recebeu do governador de Goiás uma faixa de terra de uma légua e meia de cada lado da estrada, do rio Paranaíba até o rio Grande, onde foram erguidos os aldeamentos (SAint Hilaire, 1975). Anos depois, como veremos no capítulo 3, essas terras seriam objeto de intensas disputas entre os índios e os colonos geralistas.

Tomando como base os relatos de Saint Hilaire, D’Alincourt e Eschwege, cotejados com a toponímia dos rios e córregos, e com o auxílio de cartas topográficas, estabelecemos a posição aproximada dos aldeamentos do Sertão da Farinha Podre no início do século XIX (figura 5).

\footnotetext{
Hoje Cascalho Rico

Hoje Indianópolis

10 Hoje desaparecido
} 
Os aldeamentos da Farinha Podre provavelmente se organizavam da forma estabelecida pelo Regulamento paulista de 1727, que propunha

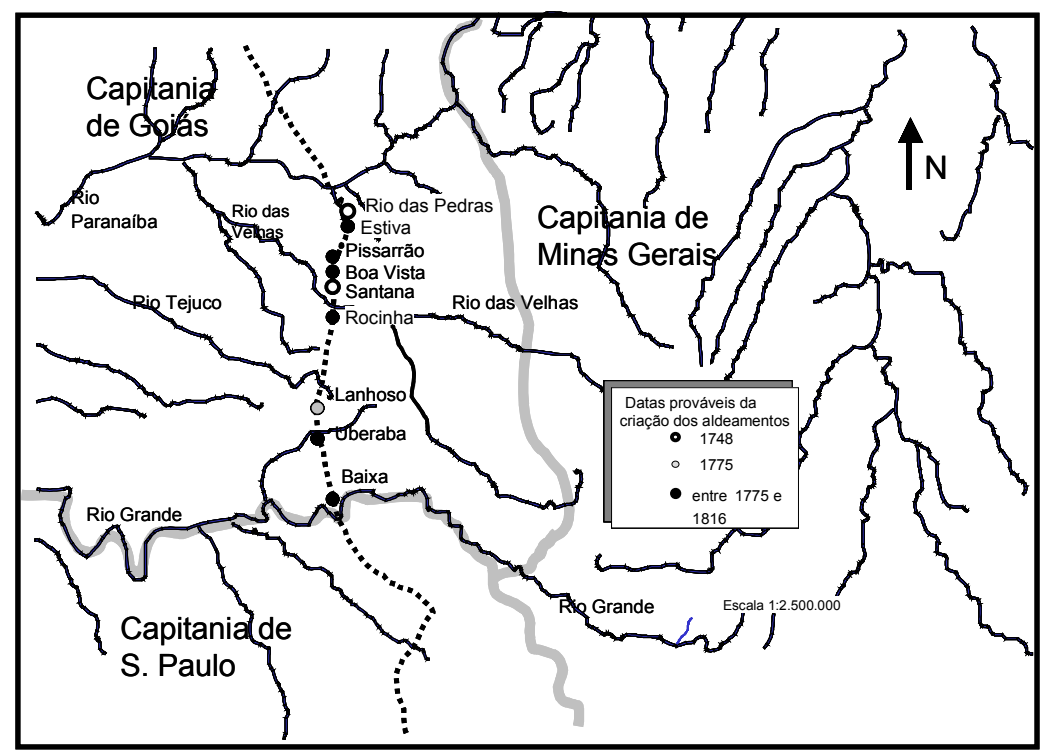

Figura 5: aldeamentos na Estrada dos Goiases (1748-1816)

Fonte: Eschwege, (1996), Sainte Hilaire (1975 a), Aires de Casal (1976).

a direção de um padre jesuíta, nomeado Protetor dos Índios, um Administrador e um Governador dos Índios, estes últimos seculares (CHAIM, 1983). O padre jesuíta José de Castilhos foi nomeado protetor dos índios dos aldeamentos triangulinos em 1749, e foi o responsável pela ereção da capela (e provavelmente pelo plano do aldeamento) da aldeia de Santana do Rio das Velhas, na beira daquele rio, um ano depois (Palacin, Garcia, Amado, 1995). Em pelo menos mais dois aldeamentos, existiam capelas Rio das Pedras e Piçarrão - , mas a capela de Santana era a única curada (Saint Hilaire, 1975). Ali foi erguida a matriz da freguesia em 1761, já depois da expulsão dos jesuítas (BARBosa, 1995). Como nos aldeamentos da região das minas goianas, os da Farinha Podre dispunham de um único administrador para todos os núcleos. 


\section{Índios soldados e índios escravos}

A historiadora goiana Marivone Matos Chaim reconstituiu o organograma administrativo dos aldeamentos goianos anteriores ao Diretório pombalino, de 1758 (figura 6), dentre os quais se incluíam os da Farinha Podre. Como se vê, a administração dos aldeamentos era feita conjuntamente por jesuítas e diretores seculares, aos quais estava subordinada uma guarda de pedestres. Como nos aldeamentos paulistas, a gestão conjunta dos inacianos e dos administradores não-religiosos era fonte de conflitos freqüentes, quase sempre versando sobre a primazia do uso da força de trabalho indígena.

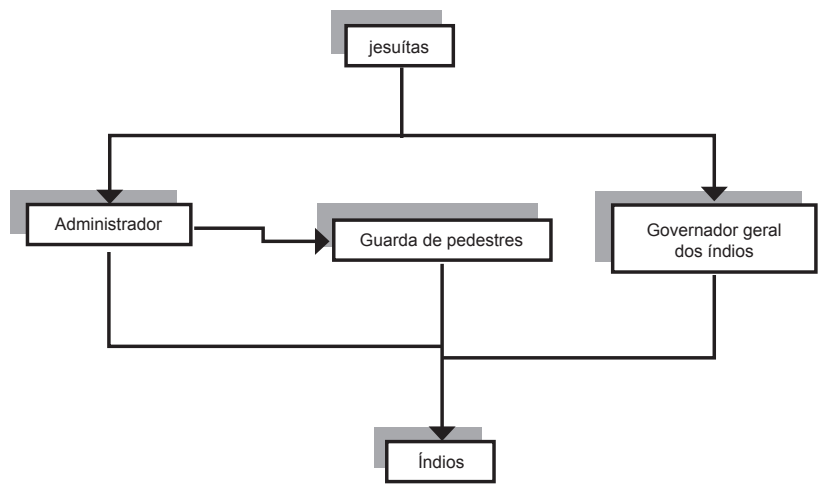

Figura 6: administração dos aldeamentos goianos até 1758

Fonte: Chaim (1983, p. 130).

Na Farinha Podre, Saint Hilaire (1975) relatou que, desde o início, os padres se indispuseram contra o primeiro administrador dos índios, o sertanista Pires de Campos. Este acabou por estabelecer-se no Rio das Pedras, enquanto os jesuítas mantiveram-se em Santana, após acordo de divisão de índios entre os dois aldeamentos. Outro exemplo de conflito entre o poder secular e o poder religioso pode ser visto numa carta de 1757, do padre jesuíta Estevão de Souza, da Aldeia de Santana, dirigida ao governador Conde de São Miguel, que falava do sucessor de Pires de Campos, guarda-mor João de Godoy. Nela, o padre pedia

pelos missionários moradores e viandantes deste sertão, se digne por serviço de Deus e Sua Majestade, livrar-nos do cruel jugo do guarda-mor João de Godoy, 
que tendo a seu cuidado a conquista do gentio caiapó, experimentamos nele um caiapó disfarçado (Palacin, Garcia, Amado, 1995, p. 72-73).

A presença de um regimento de guardas pedestres nos aldeamentos, prevista no regulamento, é significativa das duas funções que eles desempenhavam: a de defesa e de reserva de força de trabalho. Os soldados, a serviço do administrador, comandavam os indígenas em ações de defesa e ataque contra tribos hostis e, ao mesmo tempo, eram elementos de dissuasão contra a resistência deles à exploração escravista.

A disciplina nos aldeamentos, imposta pelo governo da capitania de Goiás, tinha caráter militar, que lembra a disciplina de caserna. É o que se pode perceber no Regimento emitido por D. Marcos Noronha, em 1754, e que passou a substituir o Regimento paulista de 1727:

Cap. I - os soldados darão inteira obediência àquela pessoa a cujo cargo estiver o governo da aldeia e na falta desta à que por ela ficar nomeada para fazer as suas vezes, e havendo algum soldado que desobedeça às suas ordens será logo castigado como o detido o merecer.

Cap. II - o tambor tocará alvorada ao romper da aurora, e a recolher às 8 horas da noite, e fora destas duas ocasiões não poderá tornar a tocar senão a rebate, se for preciso, e se tiver ordem para isso; a este toque se acharão logo prontos com os seus armamentos, não só os soldados, mas todos os índios, mais pessoas que assistirem na aldeia, para se lhes determinar os lugares que devem ocupar e havendo algum soldado ou índio, ou qualquer outra pessoa, que não satisfaça prontamente esta obrigação, serão logo presos, para se lhe impor os mais castigos, que o delito merecer.

Cap. III - todas as pessoas assistentes nas mesmas aldeias guardarão aos missionários todo o respeito e acatamento devido ao seu grande caráter, para que, vendo a grande estimação que se faz deles, com este bom exemplo não só façam os índios o mesmo, mas abracem com mais fervor e eficácia a nossa Santa Fé (Palacin, Garcia, Amado, 1995, p. 71).

Nos aldeamentos da Farinha Podre, o destacamento militar, comandado por um alferes, tinha quartel no Porto do Registro, no rio das Velhas, onde estava estabelecido um posto fiscal de alfândega para o trânsito entre São 
Paulo e Goiás, sob as ordens do fiel (funcionário de alfândega). Havia também destacamentos avançados na beira do rio Paranaíba e do rio Grande. O comandante do destacamento tinha a seu serviço índios da Aldeia de Santana, sob regime de administração (Saint Hilaire, 1975).

O papel defensivo e militar exercido pelos aldeamentos da capitania de Goiás era evidente, não só na Farinha Podre, onde foram criados explicitamente com esse objetivo, mas também em outros núcleos, fundados em torno da zona mineradora goiana, de 1749 em diante. O aldeamento de Nova Beira, por exemplo, na Ilha do Bananal, foi criado em 1775, junto ao Presídio (quartel) de São Pedro do Sul. Contava com índios carajás e javaés que ali haviam sido reduzidos, nativos da própria região do rio Araguaia. O governo goiano explorava então a rivalidade entre eles e grupos não aldeados, instando-os contra os caiapós setentrionais e os xavantes, que ameaçavam a navegação fluvial do rio Araguaia (Снагм, 1983).

O uso dos índios aldeados como linha militar de frente não foi uma invenção goiana. Resultava de uma longa tradição iniciada pelos paulistas nos aldeamentos do Piratininga (Petrone, 1995). Não faziam só a defesa passiva, mas também eram usados na prática do sertanismo. Monteiro (1994) confirma que o sertanismo era o principal destino dos índios do sexo masculino em São Paulo, no século XVII, sendo o trabalho na agricultura tarefa para as índias. Petrone (1995) chega à conclusão semelhante, mostrando que, com o passar do tempo, a utilização intensiva da população aldeada nas incursões pelo sertão foi um dos fatores que levou à decadência demográfica dos aldeamentos.

Nesse sentido, em Goiás, a própria expedição bororo de Pires de Campos, inaugurando na Farinha Podre o ciclo dos aldeamentos goianos, foi significativa do uso de índios no sertanismo. Posteriormente, índios do aldeamento do Rio das Pedras foram transferidos para Nova Beira, para fazer frente aos xavantes (Saint Hilaire, 1975).

Porém, o aldeamento de São José de Mossâmedes ${ }^{11}$ foi o que provavelmente mais exerceu o papel de reserva de braços para o sertanismo. Fundado em 1775, nas vizinhanças de Vila Boa, com a transferência dos índios acroás rebelados em Duro, no Leste Goiano, recebeu vários reforços demográficos posteriores, por meio de transferências compulsórias de índios de outras partes da capitania.

11 Hoje Mossâmedes 
Em 1780, recebeu os carajás e javaés de Nova Beira e, em 1813, os caiapós aldeados na Aldeia de D. Maria I, no Oeste Goiano. Esses índios foram usados nas grandes campanhas contra os xavantes, em 1788 (СНAIM, 1983).

Em Goiás, outra função importante dos aldeamentos foi a de reserva de força de trabalho escrava, explorada tanto pelos administradores quanto pelos padres e colonos. A intensiva utilização dos índios na escravidão deveu-se, principalmente, à pobreza da capitania, incapaz de importar negros da Guiné, em número suficiente para suprir as demandas locais por força de trabalho.

Em relação aos aldeamentos da Farinha Podre, há indícios que sugerem a existência de escravidão indígena no início do século XIX. No aldeamento do Rio das Pedras, por exemplo, um índio era escolhido como capitão, numa posição equivalente à do cacique nas encomiendas espanholas. Tinha como trabalho recrutar mensalmente os índios, que serviriam ao destacamento militar próximo, além de "fiscalizar as plantações e punir os preguiçosos" (SAINT HiLAire, 1975, p. 131).

Como até o início do século XIX o povoamento da região do atual Triângulo Mineiro por colonos luso-brasileiros havia sido pouco significativo, é provável que a exploração da escravidão indígena não fosse muito intensa. De fato, Saint Hilaire, referindo-se aos índios de Rio das Pedras, relatou em 1819:

Jamais vi índios tão felizes quanto aqueles. Raros eram os portugueses que se tinham estabelecido entre eles. Ninguém os incomodava, ninguém perturbava o seu repouso, e eles nem mesmo pagavam o dízimo. Tinham poucas necessidades e poucas tentações. Suas terras eram excelentes e com pouco trabalho produziam o suficiente para o seu sustento (Saint Hilaire, 1975, p. 136).

Outro papel desempenhado pelos aldeamentos da Farinha Podre, por causa de sua localização, era o de local para pousos de tropas. Os pousos eram ranchos, geralmente cobertos de sapé, abertos dos lados, onde tropas e viajantes descarregavam, dormiam e se alimentavam (SAINT HiLAIRE, 1975 a, 2000; Eschwege, 1996). Dispunham do apoio logístico da população vizinha, que preparava os víveres vendidos aos viajantes. Havia pousos em Rio das Pedras, Estiva, Piçarrão, Boa Vista, Santana e Lanhoso, onde os índios vendiam alimentos aos que lá faziam paradas (SAint Hilaire, 1975 a). 


\section{A geopolítica dos aldeamentos}

Os aldeamentos do Sertão da Farinha Podre foram criações do Estado Colonial, por meio do governo da capitania de Goiás. Sua localização resultou numa configuração territorial que refletia suas concepções sobre o uso estratégico do espaço.

Merece atenção o fato de que, ao criar aqueles aldeamentos, não parecia haver, por parte do governo goiano, a intenção de povoar. A própria disposição geográfica dos núcleos - ao longo da Estrada, no sentido sul-norte — mostrava seu caráter muito mais defensivo que propriamente de ocupação territorial. Os aldeamentos alinhavam-se como num corredor, para dar proteção e apoio logístico às tropas que transitavam de São Paulo aos arraiais goianos. Em torno destes, até o final do século XVIII, havia uma imensa área onde praticamente inexistiam povoações sedentárias coloniais. Essa configuração territorial - aglomerações regionais de povoados, isolados por zonas intermediárias não colonizadas e ligadas entre si por caminhos de trânsito obrigatório - era a que vigia em todo o centrosul brasileiro até aquele tempo, como se vê no mapa da figura 7 .

Nesse sentido, devemos nos perguntar quais seriam as razões desse peculiar arranjo geográfico. Acreditamos que a permanência de imensos espaços não colonizados — como a Caiapônia e a Bororônia de Casal, e mais o Oeste Paulista - entre os núcleos auríferos goianos e cuiabanos e o litoral, cortados por estradas de trânsito obrigatório, devia-se a fatores que iam além da presença dos "gentios selvagens".

O mito do caiapó selvagem e hostil sobreviveu até a primeira metade do século XIX. Em 1819, Saint Hilaire (1975) relatava que:

Os coiapós atacavam de surpresa as tropas de burros que vinham de São Paulo, tendo forçado os portugueses a abandonarem vários postos estabelecidos por eles na parte setentrional da província do mesmo nome (Saint Hilaire, 1975 a, p. 63).

O padre Luiz Antônio Silva e Souza, em 1812, descrevia os caiapós como uma "nação bravíssima e muito numerosa que, com os seus ataques, obstou em princípio ao aumento da capitania [de Goiás]" (Palacin, Garcia, Amado, 1995, p. 14). Eschwege, referindo-se ao Triângulo Mineiro de 1816, descreveu-o como "distritos ou julgados [que] abrangem uma área igual à de Portugal, pelo menos, 


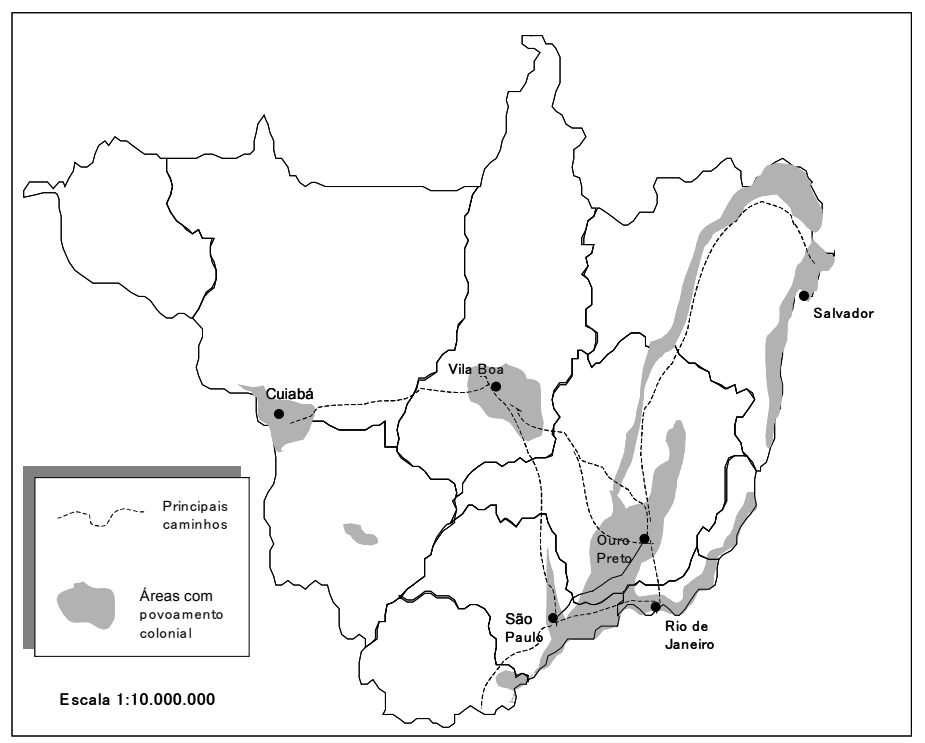

Figura 7: áreas povoadas no centro-sul brasileiro em meados do século XVIII Fonte: Holanda (1989, p. 293)

estendendo-se entre o rio Grande e o rio Paranaíba, até a sua confluência, zona até agora desconhecida por causa dos selvagens caiapós” (1996, p. 104).

É provável que as autoridades régias se interessassem em manter esse mito, por mais que a bravura caiapó tivesse fundamento na realidade. Até o período pombalino (1755-1777), não havia, da parte do Estado português, o desígnio de ocupar o interior da Colônia como um fim em si mesmo, já que o papel desta, na sua concepção mercantilista, era gerar riquezas, sobretudo auríferas. A geopolítica do Império Português relativa à Colônia resumia-se então à intenção de criar vários territórios restritos, destinados à produção de formas específicas de riqueza, ligados entre si por vias únicas e de acesso vigiado. Daí o cuidado dispensado às fronteiras entre as capitanias, e a instalação de postos militares e registros nas ligações interprovinciais. A essência das preocupações do Estado estava em extrair ouro e pedras preciosas e em evitar seu contrabando.

Nesse sentido, espaços "vazios" povoados por índios, tais como a 
Caiapônia, funcionavam como grandes barreiras naturais aos fluxos clandestinos, um desestímulo ao contrabando. A favor dessa hipótese, há o fato de que, quando se deu a abertura da Estrada dos Goiases, em 1730, foi expedida uma Carta Régia proibindo o uso de outros caminhos entre Goiás e São Paulo:

Por atalhar os grandes danos e prejuízos, que podiam seguir a Real Fazenda de Sua Majestade nos descaminhos de seus Reais Quintos, Entradas e Passagens dos Rios, e ainda dos moradores desta capitania, que não haja mais de um caminho para as Minas dos Goyazes, e se dever só conservar o que vai desta cidade à Vila de Jundiaí e continua de Mogi do Campo e dali até as ditas Minas, para cuja observância se lançou nesta cidade um Bando de 10 de janeiro de 1730, cominando-se nele as penas em que deviam incorrer os que o encontrassem (Palacin, Garcia, Amado, 1995, p. 123-124).

O mesmo cuidado existiu em relação ao isolamento das minas do Cuiabá. Pelas Ordens de 25/03/1725 e 29/04/1727, o acesso a elas deveria ser feito, obrigatoriamente, pela navegação fluvial monçoneira ou pela Estrada dos Goiases. O alvará de 27/10/1733, de forma mais abrangente e explícita, proibiu a abertura de novas estradas ou picadas para todas as zonas mineradoras (isto é, Minas Gerais, Goiás e o Cuiabá) em que houvesse arrecadação regular da Fazenda Real (Cunha Matos, 1981).

Um desses espaços "vazios" era o Leste de Minas. Nessa grande zona fronteiriça às capitanias do Espírito Santo e Rio de Janeiro, a Mata Atlântica, povoada por índios botocudos, funcionava como obstáculo natural ao extravio do ouro mineiro. Tal área, que só seria efetivamente colonizada nos séculos XIX e XX, era conhecida como Área Proibida, conforme escrito de 1784, do Capitão General Luís da Cunha Menezes: "Sertão para a parte de Leste denominado Áreas Proibidas, na hipótese de servirem os ditos sertões de uma barreira natural a esta capitania para a segurança de sua fraude" (Vasconcelos, 1999, p. 226). De fato, Cunha Matos (1981) cita o caso de um morador de Aiuruoca, punido em 1745 por abrir uma estrada clandestina de Minas ao Rio de Janeiro.

Saint Hilaire (1975) e Eschwege (1996), nos seus relatos de viagem, deixam perceber que a configuração territorial de Minas do início do século XIX ainda lembrava essa estratégia setecentista. A Estrada Real era a única 
ligação legal entre o arquipélago de arraiais do ouro mineiros e a cidade do Rio de Janeiro até 1810, quando foi autorizada a abertura de um segundo caminho, o do Rio Preto, um pouco mais ao sul (Saint Hilaire, 1975 a).

A Estrada Real, apesar de datar de 1710, não teve seus arredores povoados até o princípio do século XIX. Quando da visita dos cronistas europeus, atravessava um território ermo, coberto pela mata, onde os únicos sinais de atividade humana eram os Registros e os postos militares:

[...] enquanto que a setenta ou oitenta léguas do mar [em Minas] se encontram cidades bastante consideráveis, grande número de povoações, imensa extensão de terrenos despojados de matas, não existe, pelo contrário, a pequena distância da capital senão uma povoação nascentes; as florestas virgens se mostram aí ainda com toda a pompa nativa, e os índios erram em liberdade (SAINT HiLAIRE, 2000, p. 39).

Imagine-se uma trilha de 50 léguas, aproximadamente, aberta pelo pisoteio de mulas de carga, sombreada pela espessa mata virgem, e tendo à frente, à retaguarda e dos lados altos morros ou profundas grotas e desfiladeiros, que devemos galgar ou descer [...]. Imaginem-se as enfadonhas travessias do Paraíba e do Paraibuna, onde guardas vigilantes, fardados, como se tratasse de uma fronteira estrangeira, exigissem dos viajantes passaporte, ao mesmo tempo que exibem olhares inquisidores sobre eles (EsCHWEGE, 1996, p. 60-61).

Dessa maneira, a ocupação territorial setecentista da Colônia não mais se restringia a uma franja litorânea, como no século anterior. Desde o início do século XVIII, avançara para o binterland, com os núcleos auríferos e diamantíferos mineiros, goianos e cuiabanos, além dos portos da rede fluvial amazônica. Contudo, a configuração territorial que ia sendo gerada nesse processo não se desenhava por ocupações contíguas, com redes de núcleos interligando áreas econômicas vizinhas que penetrassem rumo ao interior, tal como o padrão descrito por Turner (2002) para o Oeste dos EUA, ou o modelo das redes dendríticas de Johnson e Kelley (CORREA, 1997). O que existia, ao contrário, era uma ocupação fragmentada, em mosaico, com territórios isolados e cercados por áreas de ocupação proibida.

A região em estudo, situada entre os rios Paranaíba e Grande, parecia ser uma das áreas cujo povoamento foi restringido pelo Estado. Até o século 
XVIII, formava, juntamente com os atuais Sul Goiano, Oeste Paulista e Mato Grosso do Sul, um imenso interstício (a Caiapônia) entre as minas goianas, mineiras e cuiabanas, onde o povoamento colonial era desestimulado.

Nessa fase, quando a geopolítica do Estado Imperial visava principalmente a proteger as regiões auríferas, o papel dos quartéis e presídios militares era muito diferente daquele que teriam no período joanino. As unidades e destacamentos militares estavam dispostos de forma a cercar as regiões auríferas, para controlar o contrabando e fiscalizar os registros e passagens.

O mapa do Oeste de Minas de fins do século XVIII, reproduzido na figura 8 , mostra as principais estradas ocidentais da capitania (em tracejado) e os postos militares (círculos com bandeirinhas triangulares). A linha vermelha representa as divisas entre as capitanias de Minas e Goiás. Percebe-se que os dois principais caminhos que as ligavam, as picadas entre Pium-i e Desemboque (que aparece como Julgado do Rio das Velhas, na parte inferior esquerda do documento) e as Picadas Velha (parte superior direita do documento) e Nova de Goiás (acompanhando grosseiramente a divisa) estavam pontuados por guardas e quartéis.

Dessa forma, o Estado Imperial Português concebia o território colonial, até meados do século XVIII, como um arquipélago de unidades regionais geradoras de riquezas, rigidamente protegidas, e isoladas umas das outras por interstícios vazios, onde os índios não-contactados e a vegetação funcionavam como muralhas naturais. Tal parecia ser o caso da região do Triângulo Mineiro, que, junto com os atuais Sul Goiano e o Oeste Paulista, isolava as minas goianas e cuiabanas, ligadas aos centros do Leste apenas pelas estradas oficiais.

No entanto, as concepções geopolíticas do Reino de Portugal, relativas ao território de sua colônia americana, mudaram muito na segunda metade do século XVIII, com a emergência do ministro Sebastião José de Carvalho e Melo, Marquês de Pombal, elevado à condição de principal figura do Estado português entre 1750 e 1777.

Pombal empreendeu, nesse período, uma ampla reforma do Estado, inspirada em concepções iluministas. O que as motivou foi a constatação da posição de inferioridade de Portugal frente às outras potências européias, principalmente a Inglaterra. Acuado pela Espanha, nas guerras e na diplomacia colonial, o país se via na contingência de manter uma aliança militar com os britânicos que, em troca, exigiam o cumprimento de um tratado comercial (o Tratado de Methuen), desfavorável aos portugueses. O déficit no comércio 


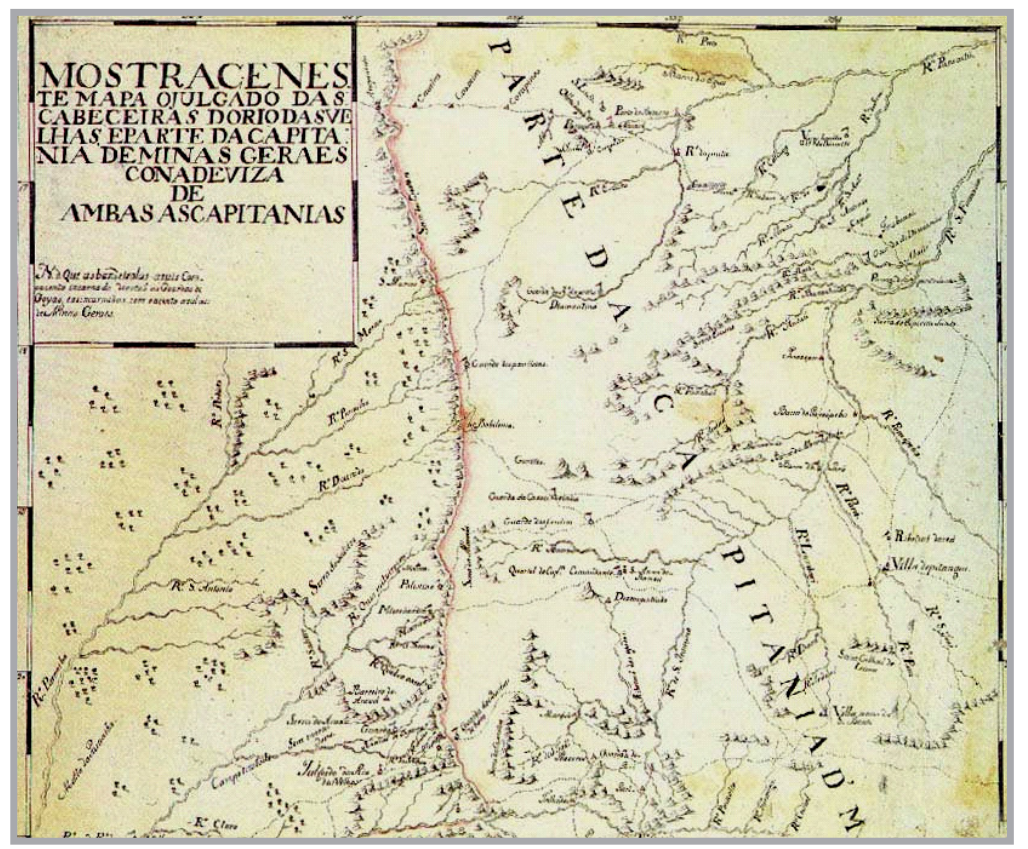

Figura 8: mapa do Oeste da capitania de Minas Gerais, em fins do século XVIII Fonte: site www.asminasgerais.com.br

com a Inglaterra era financiado pelo ouro das Minas Gerais e, por esse motivo, o monopólio sobre o comércio colonial era vital para a sobrevivência da metrópole (MAXWELL, 1996).

Pombal iniciou uma obra de engenharia política e econômica, a partir de 1755, que tinha por projeto redefinir a aliança luso-britânica em termos mais simétricos. A estratégia do ministro foi, de um lado, modernizar as instituições do Estado absolutista português, para torná-lo menos anacrônico em relação às potências do norte da Europa, e de outro, reduzir a influência britânica sobre o comércio colonial. O primeiro objetivo, para ser cumprido, necessitaria da eliminação das resistências conservadoras mais arraigadas, representadas principalmente por algumas famílias da nobreza e pela Companhia de Jesus, onipresente em algumas instituições na colônia americana, como as missões e os aldeamentos (MAXwel, 1996). 
O choque com os inacianos foi o resultado das ações de Pombal, no sentido de laicizar as instituições estatais, substituindo a elite religiosa jesuíta, que gozava de grande prestígio, por aristocratas, comerciantes e funcionários seculares a ele ligados. A tentativa de assassinato de D. José I, em 1758, forneceu o pretexto que faltava para o ministro eliminar seus inimigos. Jesuítas foram acusados de conspiração, presos, alguns executados, e em 1759, foram expulsos de Portugal e suas propriedades, confiscadas (MAXWELL, 1996).

A percepção da importância vital da colônia americana para a sobrevivência de Portugal levou o ministro a criar uma formulação geopolítica clara para o Brasil. Pombal herdara, do reinado de D. João V, o Tratado de Madri entre Portugal e Espanha que, em 1750, reconhecia a obsolescência dos termos de Tordesilhas, e estabelecia novas fronteiras na América do Sul. Tais fronteiras resultaram, em grande parte, da colonização paulista do Cuiabá e Guaporé, ao centro, e da expansão militar e jesuítica pela bacia amazônica, ao norte (MAXWell, 1996). O ministro iniciou o processo de demarcação e ocupação das divisas do extremo ocidente brasileiro, inclusive com a construção de vilas planejadas, a exemplo de Vila Bela, na beira do rio Guaporé, e Cáceres (SANTOS, 2001).

Além da demarcação de fronteiras, Pombal via como essencial o povoamento do território, como forma preservá-lo das ambições espanholas e estrangeiras em geral. Estimulou a imigração de ilhéus da Madeira e Açores para o Brasil e, principalmente, influenciado pelo intelectual iluminista duque de Silva-Tarouca, passou a ver no índio um povoador em potencial. Em 1752, o duque escrevia a Pombal:

Os reis de Portugal podem vir a ter no Brasil um império como a China. Mouros, brancos, negros, mulatos ou mestiços, todos servirão, todos são homens e são bons, se bem governados. A população é tudo, muitos milhares de léguas de desertos são inúteis (MAXwell, 1996, p. 54).

Escrevendo em 1751 a Gomes Freire de Andrade, então responsável por demarcar as fronteiras do sul do Brasil, Pombal recomendava abolir todas as diferenças entre índios e portugueses e libertá-los da tutela religiosa, para que se mestiçassem e se integrassem à massa de colonos (MAxwell, 1996). Pombal e seus colaboradores entendiam que o poder de um Estado era também poder 
demográfico, isto é, só uma grande população poderia garantir a base econômica e militar de uma grande nação. Tinha também, nas palavras de Maxwell, o "reconhecimento estratégico do interior", a consciência da identidade territorial que o Tratado de Madri criara (1996, p. 71-72).

Essa postura representou uma guinada em relação à clássica orientação do Estado português relativa ao território da Colônia, analisada linhas atrás. Até então, como vimos, o território era apenas a fonte da riqueza mercantil, e não um valor em si. Questões como a ocupação produtiva e demográfica do território colonial eram secundárias, e inclusive indesejáveis, frente à necessidade da extração de ouro ou da exportação dos gêneros da plantation. No entanto, após 1755, Pombal e seus intelectuais, bafejados pelas Luzes e deslumbrados pelo sucesso do industrialismo inglês, passaram a conceber Território e Povo como elementos centrais às estratégias imperiais.

Para implementar seu projeto geopolítico e econômico no Brasil, Pombal escalou homens de sua confiança em postos-chave da administração colonial, como D. Luís Antônio de Souza, morgado de Mateus, nomeado governador de São Paulo, e o seu próprio irmão Francisco Xavier de Mendonça Furtado, nomeado governador do Grão-Pará e Maranhão. O morgado de Mateus resumiu as instruções que recebera do ministro da seguinte forma:

O espírito [...] pode ser reduzido a três pontos principais: primeiro, defender as fronteiras; segundo, povoá-las para que possam defender-se por si mesmas, e terceiro, tornar lucrativo o uso das minas e dos benefícios que venham a ser descobertos nesse vasto continente (MAXWELL, 1996, p. 127).

No intuito de transformar o indígena num povoador, Mendonça Furtado pretendia acabar com a escravidão indígena e instituir paróquias nos aldeamentos, para que, posteriormente, pudessem se tornar vilas. Em 1754, esse homem de Pombal libertou os índios da tutela jesuíta com a publicação do Diretório que se deve observar nas Povoações dos Índios do Pará e Maranhão. Contudo, não acreditava na capacidade de autogestão indígena:

$\mathrm{Na}$ qualidade de alguém que lidou com eles [a população indígena] no dia-adia e que viveu em seus povoados durante dois anos, [que] as mais piedosas intenções de Sua Majestade serão frustradas se a esses rústicos ignorantes e 
miseráveis for dado o completo controle de seus próprios negócios [...] e como não é possível passar de um extremo ao outro sem buscar algum meio pelo qual seja possível alcançar o objetivo [da legislação], não vejo medida mais apropriada do que nomear para cada povoado um homem com o título de Diretor (MAXwell, p. 59).

Assim, substituiu a tutela religiosa sobre os índios pela tutela laica, sem, na verdade, acabar com o status de casta excluída e sujeita a escravização em que se encontravam os índios.

O Diretório foi estendido às demais regiões do Brasil em 1758, acabando de vez com o poder da Companhia de Jesus sobre os índios e transferindo todos os aldeamentos para o controle secular (MAXwELL, 1996). No ano seguinte, os jesuítas seriam definitivamente expulsos do Brasil. Nos aldeamentos, o Diretório previa a criação de escolas públicas para as crianças indígenas e proibia o uso da língua geral, tornando o português a única língua permitida. Os diretores dos aldeamentos deveriam também incentivar o estabelecimento de brancos em terras indígenas e a miscigenação (CHAIM, 1983). Tinha uma nítida intenção civilizadora, isto é, buscava erradicar as influências culturais indígenas, tidas como inferiores, e homogeneizar cultural e racialmente a colônia pela europeização e miscigenação.

Em Goiás, a aplicação das medidas do Diretório não fizeram amenizar, mas sim piorar a situação dos índios dos aldeamentos. Os homens nomeados como diretores, em sua maioria goianos, ligados aos interesses das oligarquias locais e não às intenções da Coroa, agora sem o controle e a ação moderadora dos jesuítas, viam-se desimpedidos para a prática sistemática da escravidão indígena (Karash, 1998). A permissão de que brancos se estabelecessem em terras indígenas incentivou a violência e a expulsão de índios em áreas sob jurisdição dos aldeamentos. As rebeliões indígenas ocorridas no período da vigência do Diretório atestam o nível de maus-tratos a que as populações estavam sendo submetidas. É desse período a rebelião acroá-chacriabá nos aldeamentos do Duro e Formiga, ocorrida em 1775 (CHAIM, 1983).

O governador goiano José de Almeida Vasconcelos, barão de Mossâmedes, tentou estabelecer as diretrizes pombalinas para os aldeamentos, como demonstra este trecho escrito por ele em 1771: 
[...] sem população não se podia esperar utilidade alguma da capitania de Goiás. [considerava] a impraticabilidade de se povoar a dita capitania [...] senão com os nacionais da mesma América; e que, achando-se todo o sertão daquele vasto continente coberto de índios, estes deveriam ser os que principalmente povoassem os lugares, as vilas e as cidades [...] na esperança de que, sem eles, nem poderia haver cultura, nem comércio, nem opulência, nem segurança que não fosse precária no Brasil (KARASH, 1998, p. 399).

Provavelmente, o governador teve que ceder, em vários momentos, às pressões dos fazendeiros em favor da escravização indígena, pois a decadência do ouro goiano empobrecia a capitania e tornava cada vez mais difícil a continuidade da importação de escravos africanos.

Nos aldeamentos da Farinha Podre, a ausência, ainda, de um processo efetivo de povoamento luso-brasileiro parece ter refreado, até o princípio do século XIX, a exploração escravista dos índios. Transferências forçadas ocorreram, porém, no período do Diretório pombalino, com o intuito de povoar com vários núcleos o trecho da Estrada dos Goiases situado entre o rio Paranaíba e o rio Grande. Índios bororos da Aldeia de Santana do Rio das Velhas foram transferidos para um novo núcleo, Lanhoso, nas proximidades do rio Grande, para dar lugar aos chacriabás reduzidos no Duro, no Leste Goiano (CASAL, 1976).

Santana foi transformada em paróquia em 1761, após a expulsão dos jesuítas (BARBOSA, 1995), com freguesia estabelecida sobre toda a área dos aldeamentos entre o Paranaíba e o das Velhas, seguindo a orientação do Diretório de transformar os núcleos indígenas em povoados e vilas.

No período mariano-joanino (1778-1822), moldou-se uma nova política indigenista, pela qual a exploração do trabalho indígena deixaria de ser central, sendo substituída pela questão das terras indígenas (CuNHA, 1998). Essa mudança resultou, em primeiro lugar, do aprofundamento da concepção estratégica do povoamento interior, o que decorria de um entendimento cada vez mais "moderno" de questões como Estado, Território e Soberania, principalmente com a transferência da Corte para o Rio de Janeiro, em 1808. Em segundo lugar, resultou da crescente valorização mercantil da terra em várias regiões do país, com o avanço do povoamento. As áreas vazias e "barreiras naturais" do século XVIII deixavam de ter esse papel, com a decadência da 
mineração aurífera e diamantífera, e começavam a ser ocupadas.

Com a Carta Régia de 25 de julho de 1798, D. Maria I acabou com a tutela dos diretores, prescrita pelo Diretório pombalino e, em seu lugar, instituiu a guarda particular dos índios, cedendo-os a quem pudesse educá-los, instruílos e pagá-los. Sob essa legislação, autoridades locais passaram a ser nomeadas administradores dos índios, particularmente juízes de órfãos (CunHA, 1998). Essa medida, ao retirar a tutela indígena das autoridades centrais e passá-la às autoridades locais, expôs ainda mais os índios à escravidão e às arbitrariedades.

Em Goiás, além disso, o empobrecimento da capitania levou as autoridades reinóis a perderem o interesse por ela. Cada vez mais, o governo goiano foi sendo ocupado por potentados locais, com interesses muito mais imediatistas. Com isso, na virada do século XVIII para o XIX, os índios, mais ainda do que antes, foram entregues à sanha das oligarquias goianas (KARASH, 1992).

De maneira coerente com essa nova orientação, o governador da capitania de Minas Gerais, Pedro Maria Xavier de Ataíde e Melo, recebeu, em 13 de maio de 1808, uma Carta Régia de D. João VI ordenando o início da colonização da região dos rios Doce e Mucuri, e a guerra aos índios botocudos que a povoavam:

[...] até reduzi-los aos termos de sujeição e ao estado de vida agricultora ou sedentária; que formasse um corpo de soldados pedestres para serem empregados no serviço contra os bárbaros; que se distribuísse em seis distritos o terreno infestado pelos botocudos e que, em cada um desses distritos houvesse um comandante encarregado de fazer guerra aos selvagens; que os botocudos aprisionados de armas na mão ficassem obrigados a servir ao respectivo comandante por tempo de 10 anos, ou enquanto mais durasse a sua ferocidade [...] que se promovesse o melhoramento da navegação, agricultura e comércio do Rio Doce, concedendo favores àquelas pessoas que ali se fossem estabelecer ou negociar (CunHa Matos, 1981, p. 61).

Em outra Carta Régia do mesmo ano (02 de dezembro de 1808), o governador recebeu outra ordem, complementado a anterior, de distribuir as terras resgatadas nas incursões contra os botocudos, e que os índios capturados fossem entregues aos fazendeiros da região (Cunha Matos, 1981). Alguns anos depois, uma lei de 05 de dezembro de 1812 passou a permitir, em toda 
a Colônia, o arrendamento e o aforamento de terras indígenas por colonos luso-brasileiros (CunHA, 1992).

Em Goiás, no contexto dessa nova política indigenista, a curadoria dos índios da Farinha Podre foi entregue a uma autoridade local pelo Marquês de Palma, então governador da capitania. Em 27 de outubro de 1809, o sargentomor Antônio Eustáquio Silva Oliveira, estabelecido no arraial do Desemboque, foi nomeado Comandante Regente dos Sertões da Farinha Podre e curador dos índios (SILVA, 1970). Esse ato selou o destino deles: suas terras foram espoliadas nos anos seguintes e, na segunda metade do século XIX, desapareceram completamente os registros sobre os índios da Farinha Podre. Do embate entre os colonos e os índios trataremos no capítulo 3.

\section{Economia e organização social dos aldeamentos}

Os aldeamentos indígenas tinham uma natureza diferente de outro tipo de aglomerado que existiu em seu tempo: os arraiais luso-brasileiros. Estes podiam ser considerados como povoados proto-urbanos, não só por reunirem atividades de serviço como o comércio, mas também porque havia, entre seus fundadores, a intenção explícita de um dia transformá-los em vilas, com pelourinho, vereança, casa de câmara e cadeia. Os aldeamentos eram, ao contrário, espaços impostos a seus ocupantes, criados para abrigar indivíduos tidos pela sociedade inclusa como uma casta que pairava num limbo: não eram escravos, e tampouco homens livres.

Eram escravos incompletos (GORENDER, 1988), que podiam ser explorados pelo administrador do aldeamento ou pela coletividade dos vizinhos lusobrasileiros. Mas, no seu cotidiano, viviam como camponeses, dispondo de campos de cultivo, nos quais praticavam uma agricultura de tipo familiar, com todos os elementos que caracterizavam o campesinato luso-brasileiro da mesma época: base familiar de produção, trabalho fundamentado na cooperação com reciprocidade, organização sócio-espacial baseada nos laços de parentela. Dizendo de outra forma, era como se a brecha camponesa — termo criado por Ciro Flamarion Cardoso (1987) para denominar a economia de autoconsumo própria do escravo - fosse maior nos aldeamentos que nas fazendas de plantagem, onde vigia a escravidão negra. 
Nos aldeamentos, as autoridades coloniais impunham a aculturação aos índios. A incorporação de práticas luso-brasileiras ao cotidiano da produção indígena nos aldeamentos se dava de forma gradual, começando pela negação das práticas tradicionais (embora um ou outro elemento delas pudesse permanecer) e passando pela disciplinação do trabalho, voltado para a produção de excedentes.

O que se percebe, pela descrição dos cronistas, é um painel com núcleos indígenas em diferentes fases de caboclização. Ao se comparar o tempo de aldeamento de cada população indígena, quando da passagem dos viajantes, com as observações por eles deixadas sobre seus costumes, percebe-se um grau crescente de aculturação, com abandono das técnicas ameríndias e incorporação do sistema técnico luso-brasileiro.

Um exemplo de aldeamento com uma população recentemente reduzida era São José de Mossâmedes, nas proximidades da capital goiana, visitado por Saint Hilaire (1975) e Pohl (1976) entre 1817 e 1819. Com a morte e fuga dos javaés e carajás, esse núcleo havia se despovoado, e por isso recebera, alguns anos antes da passagem dos cronistas, um grande contingente de índios caiapós meridionais, retirados da Aldeia de Maria I, onde haviam sido reduzidos em 1781 (Saint Hilaire, 1975). A redução dos caiapós no núcleo continuou nos anos seguintes, com a atividade da sertanista Damiana da Cunha, que fazia freqüentes incursões pelo Cerrado do Sul Goiano, trazendo índios ainda não aculturados e capturando os fugitivos (KARAsh, 1998). Passara-se, portanto, muito pouco tempo desde a redução dos índios no núcleo, quando da visita dos viajantes europeus.

O quadro descrito pelos cronistas em Mossâmedes mostrava índios que ainda resistiam à aculturação. Pohl encontrou homens e mulheres "quase inteiramente nus, tendo apenas os quadris envoltos em trapos” (1976, p. 151). Haviam abandonado os alojamentos construídos pelas autoridades em torno da praça maior do aldeamento, para se instalarem próximo aos seus cultivos "em cabanas construídas por eles próprios, de palmeiras, e cobertas de ervas" (1976, p. 152). Segundo Saint Hilaire, preferiam habitar tais choças porque "acharam muito frias as casas de teto alto e cobertas de telhas que lhe foram reservadas" (1975, p. 64). A divisão sexual do trabalho ainda era a da sociedade indígena tradicional, pois o botânico francês viu "várias mulheres colhendo espigas de milho, sob supervisão de dois ou três pedestres" (1975, p. 66). 
A permanência de práticas e mentalidades das sociedades horticultoras, caçadoras e coletoras foi atestada pelos comentários dos cronistas acerca da "imprevidência" e da "preguiça" dos caiapós de Mossâmedes. A ausência de práticas de estoque de colheitas, o uso do milho ainda verde, típico das sociedades pré-cabralianas (e não o milho maduro como cereal, como nas sociedades coloniais), a presença de jogos de caça e a ausência de elementos ideológicos ligados à acumulação material foram assim vistos por eles:

Esses índios são como todos os outros, volúveis e totalmente imprevidentes. Ao fazerem a colheita, em suas plantações particulares, raramente esperam que os frutos ou grãos estejam perfeitamente maduros. Nunca pensam no dia de amanhã, não guardam nada, vivendo apenas a hora presente [...] (SAINT Hilaire, 1975, p. 69).

As suas ocupações favoritas são caçar, perambular pela mata e pescar, mas nisso não se esforçam muito. Quando caçam um animal, o que não é trabalhoso, dada a abundância deles na mata virgem, descansam o dia inteiro, deitam-se e entregam-se à ociosidade (PoHL, 1976, p. 154).

A aculturação e a submissão dos índios aos interesses coloniais, mediante sua escravização, era uma das funções a que se destinavam os aldeamentos. Assim, em Mossâmedes, eram submetidos a uma rígida disciplina de trabalho, supervisionados pelos soldados pedestres ali aquartelados. Trabalhavam cinco dias por semana nas roças do aldeamento, folgando aos domingos e segundas feiras, quando cuidavam de suas roças particulares. As índias dispunham de um descaroçador de algodão e mais vinte e quatro rodas de fiar, e eram instruídas por uma mulher, paga pelo diretor do aldeamento, para que aprendessem as técnicas luso-brasileiras (Saint Hilaire, 1975).

Já nos aldeamentos da Farinha Podre, onde a população indígena se encontrava reduzida há muito mais tempo que em Mossâmedes (desde meados do século XVIII), os cronistas encontraram um processo de aculturação bem mais avançado. Neles, a agricultura de subsistência era a principal atividade econômica dos índios, embora a caça e a coleta ainda compusessem uma parte de sua dieta (Saint Hilaire, 1975). As famílias viviam juntas no núcleo, e diariamente os homens se deslocavam para os campos de cultivo, enquanto 
as mulheres permaneciam em suas casas, envolvidas no trabalho do artesanato e no beneficiamento dos produtos agrícolas, numa divisão sexual do trabalho já tipicamente luso-brasileira. Eschwege (1996), visitando a região em 1816, encontrou apenas mulheres em Santana, numa segunda feira, pois os homens achavam-se todos nas lavouras. Saint Hilaire (1975) pôde encontrar todos os moradores da Aldeia da Estiva à noite, quando os homens voltavam de seu trabalho. Mais adiante, ao passar por Santana, fez a mesma observação que Eschwege: "Quando cheguei só encontrei mulheres; os homens se achavam todos na lavoura" (1975, p. 143).

Também a cooperação e a reciprocidade, dos quais o melhor exemplo é o mutirão, existiam nos aldeamentos triangulinos. O naturalista francês assim relatou sua chegada à Aldeia de Boa Vista:

Quando cheguei era dia de festa. Um de seus moradores tinha acabado de derrubar um trecho da mata, o qual, depois de queimado, iria servir para fazer uma roça. Todos os lavradores pedem a ajuda dos vizinhos para este tipo de serviço e em seguida lhes oferece um repasto, com muita cachaça, o qual termina sempre com danças e batuques (Saint Hilaire, 1975, p. 135).

O trecho mostra não só a prática da reciprocidade, mas também a comemoração oferecida pelo beneficiado, o que, na verdade, é característico do campesinato luso-brasileiro. D’Alincourt (1975), contemporâneo de Saint Hilaire, descrevera a mesma prática entre moradores da beira do rio Capivari, próximo a Jundiaí, e Antônio Cândido (2001), entre os caipiras paulistas nos anos 1950. Como veremos no capítulo 4, essa prática recebia no Triângulo Mineiro o nome de treição.

A produção agrícola destinava-se quase inteiramente ao autoconsumo, mas havia um pequeno excedente que era trocado por gêneros como o sal e ferramentas, por meio das tropas vindas pela estrada do Anhanguera (SAINT Hilaire, 1975). O algodão e o milho eram os principais gêneros cultivados, mas não havia entre eles a pecuária bovina, sendo essa atividade exclusiva dos colonos brancos (Eschwege, 1996). Eschwege relatou a presença de um monjolo no centro do largo principal de Santana, destinado ao uso coletivo. Como veremos, a pilagem de grãos com o uso do monjolo é uma técnica ibérica, incorporada ao complexo produtivo colonial.

A atividade artesanal feminina, sobretudo tecelagem e cerâmica, tinha 
grande importância na formação do excedente comercializável. As trocas eram feitas não só com os tropeiros da estrada, mas também com os fazendeiros luso-brasileiros vizinhos, que lhes forneciam, no escambo, carne, cachaça e rapadura (SAINT HiLAIRE, 1975). Alguns índios, inclusive, acabaram se tornando fazendeiros, como o chefe Leopoldo de Rio das Pedras, dono de um engenho de açúcar e fábrica de aguardente (EsCHwEGE, 1996).

A presença da tecelagem e da cerâmica sugere a permanência de algumas técnicas pré-cabralianas entre os índios da Farinha Podre. Pasquale Petrone (1995) relata o mesmo tipo de atividade entre os índios dos aldeamentos paulistas até meados do século XIX, destacando ainda que o comércio do artesanato e a atividade dos jornaleiros tornaram-se, com a perda das terras ou seu esgotamento, as únicas alternativas de sobrevivência para os índios de Itaquaquecetuba, Barueri, São Miguel e Pinheiros ainda em 1845. Sobre essas técnicas, não dispomos de informações que nos permitam maiores detalhes, por exemplo, se usavam o tear vertical indígena ou o horizontal português.

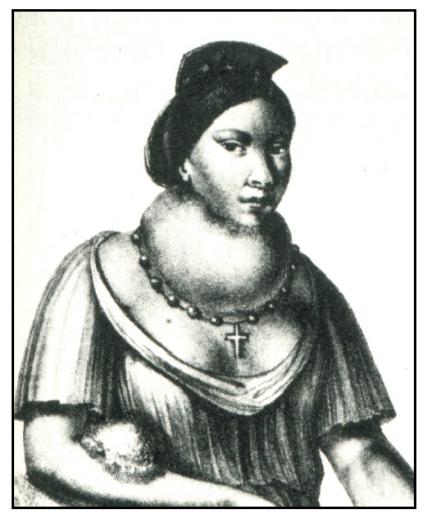

Figura 9: Mameluca com bócio (Spix e Martius, 1981)

Uma prova indireta da aculturação sofrida pelos índios da Farinha Podre pode ser fornecida pela epidemiologia do bócio endêmico entre os índios, rastreada pelos relatos dos cronistas. Essa doença, uma hipertrofia da glândula tireóide provocada pela carência de iodo na dieta (MAZZAFERRI, 1988), é evidenciada por um grande papo, visto na porção anterior do pescoço (figura 9). Hoje pouco freqüente, devido à obrigatoriedade de iodação do sal de cozinha e pela melhora 
do padrão nutricional da população, o bócio era, todavia, de alta prevalência no Brasil Colonial, como se pode perceber pelos relatos dos naturalistas do período joanino. Isso se devia à ausência do sal iodado, que não era compensada pela dieta colonial, rica em carboidratos, mas pouco diversificada e carente em proteínas de origem animal. ${ }^{12}$

Os povos indígenas, no entanto, eram pouco suscetíveis à doença, por terem uma dieta mais diversificada que a população luso-brasileira, graças a maiores opções nutricionais oferecidas pela caça e coleta. Falando dos caiapós de Mossâmedes, Pohl relata que "é notável que esses índios sejam imunes ao bócio, de que se acham acometidos quase todos os europeus e negros residentes na aldeia" (1976, p. 155). Isso demonstra que, naquele momento, ainda não havia ocorrido uma completa assimilação, por eles, da dieta luso-brasileira.

$\mathrm{Na}$ Farinha Podre, contudo, Saint Hilaire encontrou uma situação epidemiológica muito mais próxima da realidade colonial, o que certamente refletia a aculturação dietética. Em Rio das Pedras, observou que os índios bororos "têm o peito largo, o pescoço curto e grosso, quase sempre acrescido de um enorme bócio" (1975, p. 129).

Os núcleos dos aldeamentos não dispunham de estabelecimentos comerciais sedentários, tampouco oficinas de ofícios (SAint Hilaire, 1975), sendo o artesanato uma atividade eminentemente doméstica. A explicação, provavelmente, é que não havia escala suficiente de comercialização e demanda por serviços, devido à baixa margem de produção de excedentes na economia indígena, não induzindo, portanto, à formação de uma classe de artesãos e comerciantes exclusivos. O comércio era feito diretamente pelos índios com os tropeiros, para os quais existiam ranchos de pouso, e com os fazendeiros, que levavam seus gêneros aos aldeamentos (Saint Hilaire, 1975).

\section{O sítio e o traçado dos aldeamentos}

Em seu opúsculo Vilas e Cidades no Brasil Colonial, Aroldo de Azevedo (1957) mostra como houve intencionalidade na escolha de sitios em acrópole -

12 Para uma análise da dieta colonial e suas relações com doenças endêmicas, ver Castro (sd). Uma discussão sobre as condições nutricionais da região central do Brasil e a epidemiologia do bócio endêmico se encontra nas páginas 240 a 244. 
sítios sobre pontos elevados com domínio visual da paisagem circunvizinha — no processo de criação dos primeiros aglomerados urbanos no Brasil. Rio de Janeiro, erguida sobre o Morro do Castelo, a Cidade Alta de Salvador, e São Paulo, erguida no espigão entre o rio Tamanduateí e o córrego do Anhangabaú, foram exemplos de como a preocupação com a defesa foi fundamental ao urbanismo colonial.

Também como parte dessas preocupações, a necessidade do amuralhamento fazia desses primeiros núcleos vilas e cidades fortificadas, que lembravam bastidas medievais, como os castros portugueses. No caso do Rio de Janeiro, Cidade Filipéia, ${ }^{13}$ Salvador, Natal, Fortaleza e Belém, todas nascidas já cercadas de muralhas e baluartes, havia a preocupação óbvia com a defesa marítima. Mas em São Paulo, cidade interior e boca de sertão desde o final do século XVI, também foram erguidos muros de taipa batida cercando todo o sítio urbano, de forma a resguardar a vila contra os ataques dos indígenas: até o início do século XVII, ainda havia a ameaça de grupos hostis vizinhos, como os guaianases e os guarulhos.

Petrone (1995) demonstrou, de forma convincente, que o sítio em acrópole predominou também no planejamento dos aldeamentos circunvizinhos à vila de São Paulo. Embora a preocupação com a defesa estivesse presente em tempos tão instáveis, havia também a necessidade de se ter acesso às aguadas. Daí a escolha de pontos que, embora estivessem a cavaleiro dos rios, também fossem situados a jusante dos seus cursos. A escolha, portanto, quase sempre recaía sobre os terraços fluviais, locais próximos aos rios, mas abrigados de suas cheias. Foi o caso, num dos estudos do autor, do sítio de Pinheiros, na margem direita do rio do mesmo nome, aproximadamente 10 metros mais alto do que a várzea vizinha.

Quanto aos aldeamentos da Farinha Podre, não temos informações precisas, mas aproximadas, dos sítios da Estiva, Piçarrão, Boa Vista e Lanhoso. Não sabemos se o sítio de Rocinha correspondia exatamente ao atual povoado de Tapuirama, pois este teve seu patrimônio delimitado e sua capela construída recentemente, em 1933. Temos a localização aproximada do sítio da Aldeia de Uberaba, pois até 1860 ainda eram vistos os restos do seu cemitério (PONTES, 1978). Os sítios dos aldeamentos de Rio das Pedras e Santana do Rio das Velhas correspondem,

13 Hoje João Pessoa 
respectivamente, às atuais cidades de Cascalho Rico e Indianópolis.

O sítio do aldeamento de Rio das Pedras encontrava-se numa elevação entre o córrego da Grota, um outro córrego menor e a cavaleiro do rio das Pedras (BArbosa, 1998). A posição dominante sobre uma colina era também a de Santana do Rio das Velhas, situada sobre o espigão entre os córregos Manoel Velho e Lava Pés, aproximadamente a 35 metros acima do vale escavado por este último (figura 10).

Em todos eles, percebe-se a intenção do sítio em acrópole, e ao mesmo tempo a jusante de cursos d'água, seguindo o mesmo padrão dos núcleos paulistas. Não poderia ser de outra forma, pois, como já visto, os aldeamentos triangulinos foram criados com a explícita intenção de funcionar como postos de defesa ao longo da Estrada do Anhanguera.

Outra diferença entre os aldeamentos e os arraiais era quanto ao traçado. Autores, separadamente, estudaram um e outro tipo de aglomerado, mas não tivemos acesso a nenhuma síntese mostrando diferenças e semelhanças entre ambos. Murilo Marx (1991) escreve que, diferente da América Espanhola, o Brasil não contou com algo parecido com as Leyes das Índias, a rígida legislação pela qual a Coroa espanhola impunha um modelo urbanístico uniforme às cidades das suas colônias. Demonstra que isso não significou, diferente do que diz Paulo Santos (2001), que a cidade colonial brasileira fosse um exemplo de "cidade informal", irregular no traçado e espontânea no crescimento.

Havia uma regulamentação, não secular, mas religiosa, que os próprios colonos faziam questão de aplicar, para que suas capelas fossem reconhecidas pelas autoridades eclesiais e se transformassem em paróquias (MURILO MARX, 1991). Tal regulamentação estava codificada nas Constituições Primeiras do Arcebispado da Bahia, que governava todo o clero brasileiro, e que estabelecia as posturas que deveriam ser seguidas pela Igreja no Brasil.

Assim, a constituição 687 determinava que:

Conforme direito canônico, as Igrejas se devem fundar, e executar em lugares decentes, e acomodados, pelo que mandamos, que havendo-se de edificar de novo alguma Igreja paroquial em nosso Arcebispado, se edifique em sítio alto, e em lugar decente, livre de umidade, e desviado, quanto for possível, de lugares imundos e sórdidos (Murilo Marx, 1991, p. 22). 
Mais adiante, a mesma constituição estabelecia que as igrejas paroquiais estivessem livres de "casas particulares, e de outras paredes, em distância que possam andar as procissões ao redor delas" (Murilo Marx, 1991, p. 22-23). Essas disposições definiam uma posição dominante do templo, com sua porta voltada para a parte mais baixa, e seus arredores livres de outras edificações, definindo o espaço do adro. A partir deste, num ordenamento ortogonal, se traçavam as ruas e travessas do povoado.

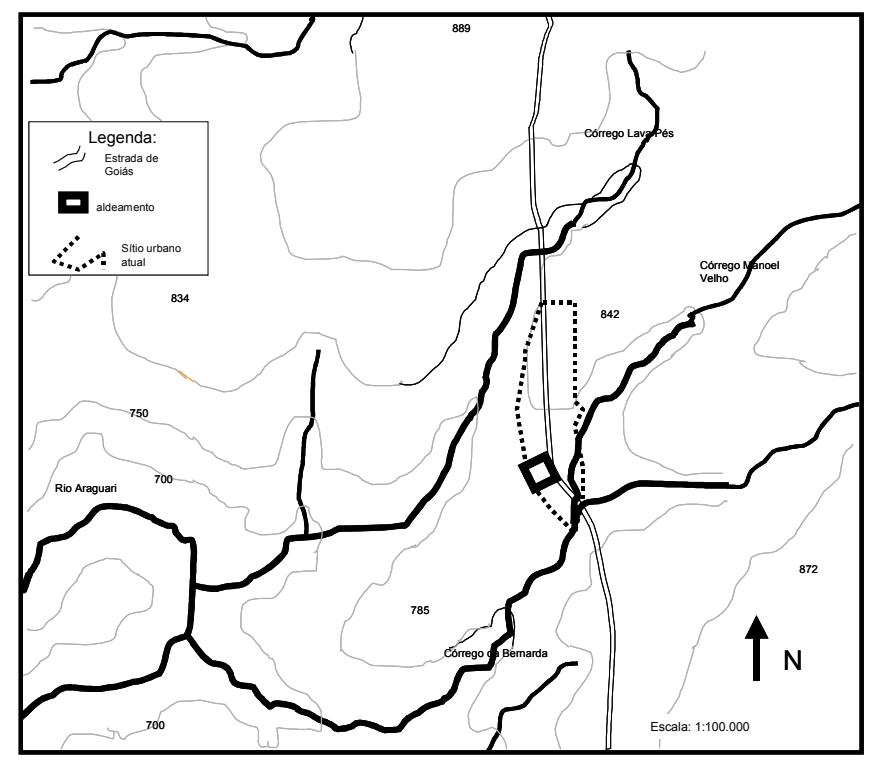

Figura 10: Sítio provável do aldeamento de Santana do Rio das Velhas Fonte: Saint Hilaire (1975), D’Alincourt (1975), IBGE (1972).

Os aldeamentos indígenas no Brasil obedeciam a um traçado diferente dos arraiais. Planejados pelos jesuítas, não estavam sob influência direta do Arcebispado da Bahia, mas tiveram como modelo, segundo Petrone (1995), as missões criadas na América Espanhola, regulamentadas pelas Leyes das Índias. Estabeleciam a obrigatoriedade de um adro em formato retangular, com o templo e casas unidos lado a lado e voltados para o centro do largo, "para que sirvam de defesa e força contra os que a quiserem estorvar ou infestar" (Petrone, 1995, p. 230, 232). Ainda, os lados da praça maior deveriam estar orientados no sentido norte-sul, para receber os ventos dessas direções. Isso 
fez os aldeamentos brasileiros mais parecidos com as missões guarani-jesuíticas do Sul ou com as cidades da América Espanhola do que com os arraiais lusobrasileiros.

Os aldeamentos da Farinha Podre também tinham essa disposição, pelo menos o de Santana. A descrição que Saint Hilaire fez desse núcleo é clara:

A aldeia foi construída numa região descampada e no alto de uma colina, ao pé da qual passa um córrego cujas águas vão se juntar ao Rio das Velhas. É composta de umas trinta casas muito pequenas, quase quadradas e cobertas de palha. Algumas ficam espalhadas pela colina, sem nenhuma ordem, enquanto outras se enfileiram ao redor de uma praça de formato quadrangular, com um dos lados ocupado pela igreja, que é muito pequena (SaINT HiLAIRE, 1975, p. 143).

Seu testemunho é reforçado pelo de seu contemporâneo Luiz D'Alincourt, que por lá passara um ano antes: "[A Aldeia de Santana] tem uma ermida, e em frente a ela um largo retangular, ornado de casas pequenas cobertas de palha, e algumas de telha. Fora do largo há mais algumas casas dispostas avulsamente" (1975, p. 78). Como nos aldeamentos paulistas, a única regularidade era a imposta pela praça maior, não havendo arruamento definido ao redor dele (PETRONE, 1995).

Dispomos do testemunho material da matriz de Nossa Senhora de Santana, em Indianópolis, erigida em 1844 no mesmo sítio da antiga capela do aldeamento (PMI, s/d). O atual traçado da cidade não corresponde ao da primitiva aldeia, pois foi totalmente modificado pelo prefeito Nelson Soares de Oliveira, em 1939, quando da fundação do município. Por isso, a igreja de Santana tem sua fachada desalinhada em relação à rua atual (figura 11). A fachada está voltada para o rumo oeste, de forma que os lados do adro primitivo, possivelmente, dispunham-se na direção norte-sul, paralelos à Estrada do Anhanguera.

As imagens que nos chegam de outros aldeamentos criados pela capitania de Goiás revelam a mesma disposição. A finalidade era provavelmente defensiva, pois as casas, cerradas junto da igreja, funcionavam como uma muralha tosca, uma primeira linha de defesa contra agressores. É o caso do aldeamento de Mossâmedes, criado alguns anos depois de Santana, que lembra muito um presídio militar setecentista (figura 12).

A prova definitiva da influência jesuítico-espanhola no plano dos aldeamentos paulistas e goianos está na comparação de plantas das missões do 


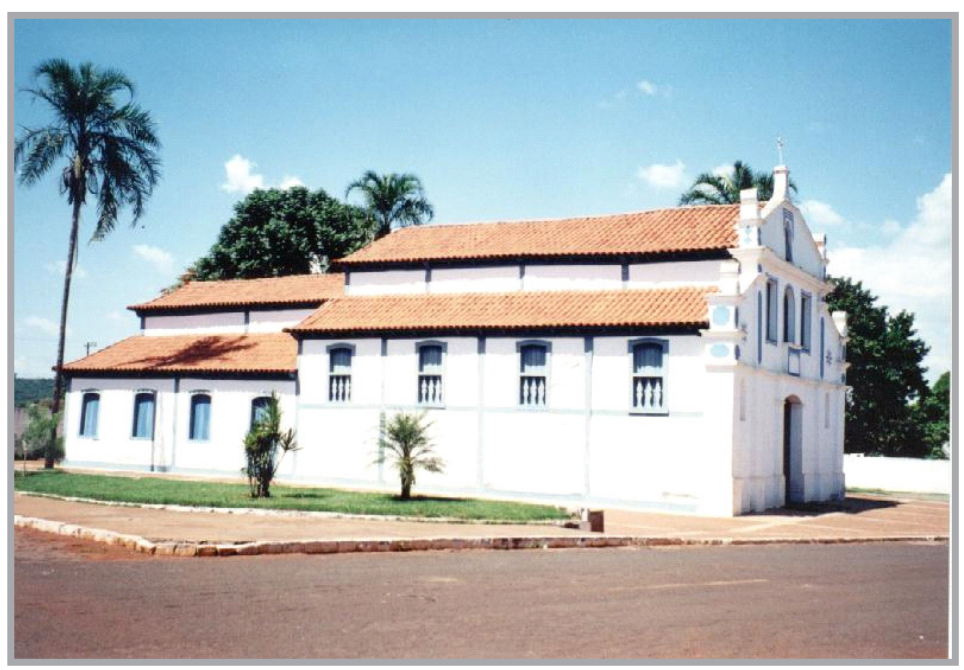

Figura 11: Igreja Matriz N. Senhora de Santana, construída no aldeamento de Santana dos Rio das Velhas em 1844

Fonte: foto Lourenço, L. A. B. (2001).

Guaíra e Tape com a destes últimos. Mesmo separadas por mais de um século, é admirável a semelhança, por exemplo, entre a planta da missão de Santo Inácio Mini, construída no final do século XVII nas margens do rio Paraná, em território hoje argentino ${ }^{14}$ (figura 13), e o plano para um aldeamento goiano de índios caiapós, de 1782 (figura 14).

Em ambos, o adro quadrangular tem o templo disposto em posição mediana de um dos lados, e voltado para o largo. Nos lados, estão os alojamentos dos índios e as vias, que partem do largo em disposição ortogonal. Atrás da igreja, um campo para cultivos coletivos. É interessante notar que a planta da aldeia caiapó data de 1782, vinte e três anos depois da expulsão dos jesuítas, e num momento em que os aldeamentos já se encontravam subordinados a autoridades seculares, e não mais à Companhia de Jesus.

Criara-se um modelo que passou a se repetir em todo aldeamento, subordinado ou não às autoridades inacianas. E, provavelmente, isso ocorria porque era eficaz, não só como um sistema de defesa, que imitava um

14 Seus vestígios arqueológicos foram estudados em 1901 (LugON, 1977). 


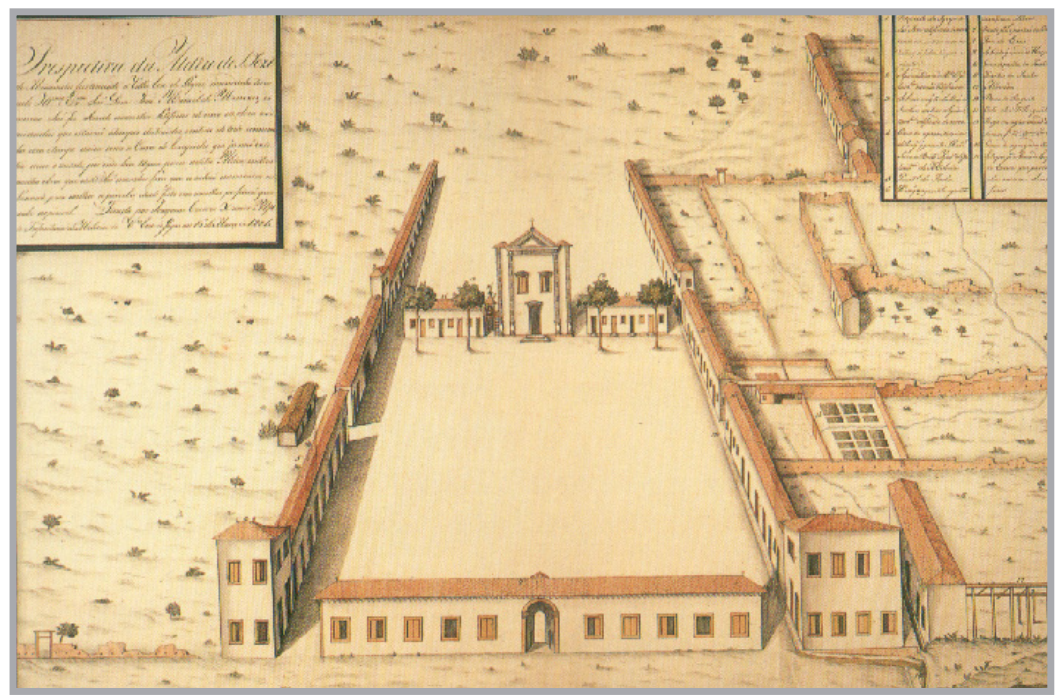

Figura 12: aldeamento de São José de Mossâmedes Fonte: Goulart Reis (2001).

amuralhamento, mas também porque facilitava a vigilância sobre todos os índios, expostos ao olho das autoridades eclesiais e seculares em torno do adro, num panóptico muito parecido com o benthaniano. A rígida disciplina militar dos aldeamentos goianos; a presença obrigatória de destacamentos militares exercendo controle e comando; as rebeliões que, como vimos, mostravam o caráter compulsório da moradia indígena no aldeamento, tudo isso tornava funcional (do ponto de vista das autoridades) o modelo criado a partir das Leyes. Dessa forma, parece claro o caráter de instituição disciplinar dos aldeamentos, um lugar onde o poder colonial impunhase aos índios. Para usar uma palavra daqueles tempos, era o lugar onde recebiam a civilização.

\section{Demografia e mobilidade espacial}

Os aldeamentos indígenas criados pelo Estado Colonial não se assemelhavam a núcleos pré-urbanos, mas a aldeias, tal como conceituadas 


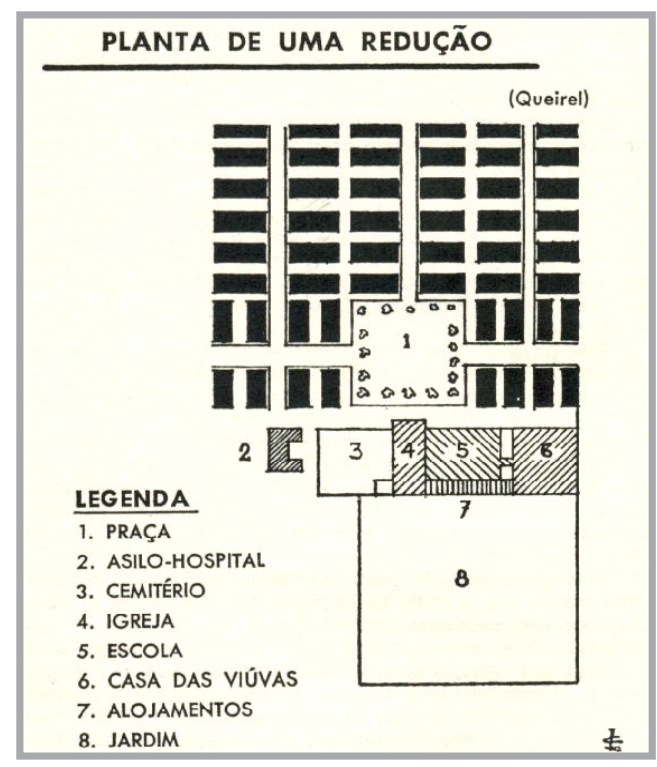

Figura 13 : missão de Santo Inácio Mini Fonte: Lugon (1977).

por Petrone (1995): uma forma de habitat rural concentrado. O termo aldeia era usado em Portugal para designar aglomerados camponeses, equivalente ao villagio italiano ou à village francesa. No Brasil, os colonizadores passaram a designar de aldeias, indistintamente, tanto as tabas indígenas, isto é, os aglomerados de origem pré-cabraliana, quanto os aldeamentos, núcleos de reclusão indígena compulsória. Continua o autor, o rótulo de aldeia seria uma forma de caracterizar a inferioridade do aglomerado indígena, associando-o ao rural e, portanto, inferior aos arraiais e vilas: estes teriam caráter urbano, mesmo se tratando de aglomerações extremamente modestas.

Mais do que um simples jogo de palavras, as denominações aldeamento e arraial revelam diferenças fundamentais entre os dois tipos de aglomerado, na lógica e na mentalidade coloniais, mesmo quando aparentemente não houvesse nenhuma diferença na economia, estrutura ou demografia entre um e outro. Os arraiais, desde o momento da ereção da capela e delimitação do patrimônio, já mostravam a intenção de uma coletividade de colonos de 


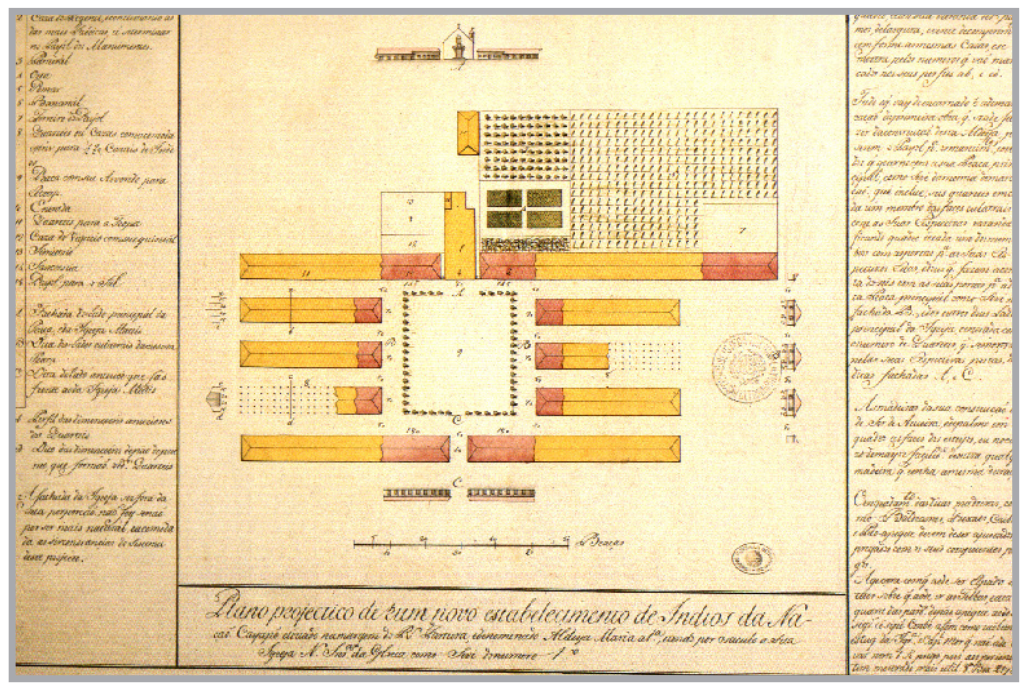

Figura 14: planta do aldeamento de Maria I.

Fonte: Goulart Reis (2001)

constituir um núcleo que, ao mesmo tempo que funcionasse como elo com a sociedade inclusa, seria a forma espacial de sua identidade e territorialidade. Essa identidade se expressava na devoção coletiva a um santo, em cuja honra era erigida a capela, e em laços de parentesco e vizinhança, que gradualmente iam se estreitando. O próximo passo era a constituição da paróquia e freguesia e, mais tarde, com a casa de câmara e cadeia e o pelourinho, o reconhecimento da vila e da municipalidade.

Desse modo, a comunidade de vizinhança aspirava ser reconhecida pelas autoridades eclesiais e estatais, esse reconhecimento sendo um elemento de reforço da sua própria identidade. Daí a necessidade, desde o início, da identificação do arraial com o urbano, mesmo quando não passasse de uma modesta capela rodeada por taperas. E daí insistirmos no termo proto-urbano aplicado a ele, sem que isso signifique qualquer distorção teleológica. Disso derivava o caráter centrípeto dos arraiais, isto é, a sua tendência a atrair moradores, comércio e ofícios, e sua tendência, via de regra, ao crescimento. Elemento de identidade de uma comunidade, à medida que ela crescia tendia a concentrar no povoado suas demandas de toda espécie, o que contribuía para fixar-lhe uma população sedentária. 
Os aldeamentos, nesse sentido, não eram povoados proto-urbanos. A aglomeração era imposta aos índios pelo poder coercitivo da Igreja ou do Estado, para finalidades de defesa, escravização ou catequese. Não havia qualquer aspiração autônoma ao reconhecimento dos núcleos como urbanos, já que sobre eles pesava o estigma de aldeia (isto é, de não-urbano) e habitat indígena (de não-livres e não-brancos), o que implicava uma total heteronomia.

Mesmo as mudanças que a política pombalina tentou implementar por meio do Diretório, como a transformação dos aldeamentos em freguesias, acabaram se frustrando por causa do ranço que pairava sobre os índios: os colonos e as autoridades locais faziam letra morta das determinações legais, mantendo a escravização, a espoliação de terras e negando o status de urbano às paróquias dos aldeamentos. O que nos leva à hipótese de que, na verdade, os índios aldeados compunham uma casta, no sentido empregado por Florestan Fernandes e Roger Bastide (1975), isto é, um estamento que não compartilhava do mesmo ordenamento jurídico dos homens livres.

A tendência centrífuga dos aldeamentos, ou seja, sua tendência ao despovoamento, já havia sido detectada por Petrone (1995) no caso paulista. Nos aldeamentos do Piratininga, à medida que havia esgotamento de terras, a tendência dos índios era de se mudar dos núcleos para junto de suas roças, numa dispersão que as autoridades tentavam reverter pela força.

Outro fator de dispersão era a espoliação de terras indígenas promovida por proprietários brancos, que ia reduzindo as áreas cultiváveis dos aldeamentos, até obrigar os índios a abandoná-los. O expediente de aforar terras indígenas e depois expropriá-las ilegalmente parece ter sido muito usado pelos colonos luso-brasileiros, tanto que, entre os núcleos piratininganos, o da Escada foi o que manteve por mais tempo as terras cultiváveis, porque os padres haviam proibido de aforá-las aos brancos (Petrone, 1995).

Nos aldeamentos da Farinha Podre, a tendência demográfica centrífuga também foi dominante. Saint Hilaire (1975), ao passar pela Aldeia do Piçarrão, em 1819, relatou que muitos habitantes do núcleo haviam abandonado o local e se fixado nas redondezas. Na Aldeia do Lanhoso, encontrara somente duas choupanas miseráveis, e seus moradores disseram que parentes seus estavam estabelecidos pelas vizinhanças. Três anos antes, Eschwege (1996) encontrara índios vivendo de forma dispersa, bem distantes dos núcleos dos aldeamentos, ao longo do trecho da Estrada dos Goiases entre o aldeamento de Rio das Pedras e o rio Paranaíba. 
Na verdade, os núcleos de Estiva, Boa Vista, Rocinha, Lanhoso, Uberaba e Baixa não eram aldeamentos strictu sensu, mas sítios indígenas, ${ }^{15}$ resultado da dispersão espontânea da população, ao longo da faixa de terras aldeanas, a partir dos aldeamentos verdadeiros - Rio das Pedras, Piçarrão e Santana. D'Alincourt referiu-se a Boa Vista como pouso e depois como sitio, onde vivia uma única grande família indígena:

Os moradores desse sítio [da Boa Vista] são índios, divididos em várias famílias, que todas trazem na origem um velho de mais de cem anos, que ainda governa o lugar e que já tem netos de seus netos: as casas dessa gente são cobertas de palha (D’Alincourt, 1975, p. 78).

Saint Hilaire relatou que a Aldeia do Piçarrão havia sido fundada pelas autoridades goianas, com o desmembramento da população de Rio das Pedras, para formar um outro pouso que pudesse servir às tropas, 21 quilômetros mais ao sul. Os índios, contudo, por causa do esgotamento dos solos em torno do Piçarrão, formaram mais outras duas localidades — as já citadas Estiva e Boa Vista - , respectivamente, a 10 quilômetros ao norte e 12 quilômetros ao sul daquela paragem. O naturalista francês destacou que sempre, todavia, se estabeleciam às margens da Estrada, onde se beneficiavam do acesso à passagem das tropas, mediante a venda de seus excedentes (1975 a). Vigário Silva (1970), primeiro pároco da freguesia de Uberaba e contemporâneo de Saint Hilaire, descreveu o mesmo padrão de ocupação:

[Até 1807] era apenas conhecida a estrada, que a atravessa de S. Paulo para Goiás, onde residião alguns índios, que tinham saído da Aldeia de Santa Ana, os quais nunca tiveram ânimo de alongar-se para algum dos lados da mesma estrada, nem ao menos meia légua, como depois se conheceu pelas suas culturas sempre vizinhas de suas habitações (1970, p. 07).

Desse modo, nos aldeamentos triangulinos a tendência migratória também era de dispersão, talvez causada pelo esgotamento dos solos, cultivados com pousios curtos. Havia, contudo, uma tendência de os índios se estabelecerem

15 Chamavam-se sitios ou situações as unidades de produção agropastoris no período colonial. 


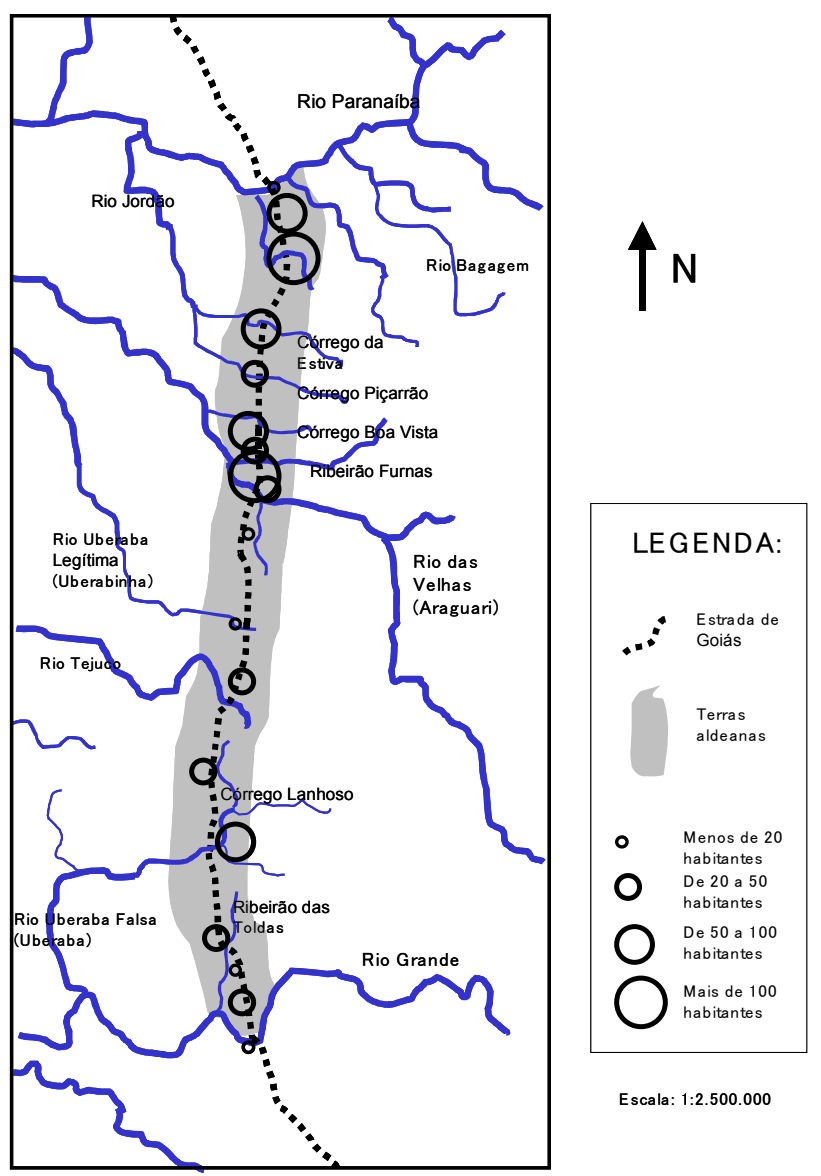

Figura 15: distribuição da população indígena em terras aldeanas do Sertão da Farinha Podre em 1821

Fonte: Eschwege (1996), IBGE (1972).

sempre dentro das terras aldeanas, já que estas consistiam numa área bastante grande, de aproximadamente 3.460 quilômetros quadrados. Eschwege (1996) reproduziu um mapa demográfico, feito pelos representantes dos índios da Farinha Podre em 1821, constando do número e do nome das paragens em que então se encontravam as famílias indígenas. Cotejamos essas informações com as cartas topográficas do IBGE (1972), para produzirmos o mapa da figura 15, 
com a localização aproximada dos núcleos de famílias indígenas em 1821.

Como se pode observar, os núcleos espalhavam-se ao longo de todo o traçado da Estrada, mas havia uma tendência a confluírem em dois trechos: do rio Paranaíba ao rio das Velhas, e do rio Tejuco ao rio Grande. Comparando-se essa distribuição com uma carta de solos do Triângulo Mineiro (figura 16), nota-se um claro liame entre os núcleos indígenas e as áreas de latossolo roxo (em cor negra), adequados para cultivos. Percebe-se, igualmente, uma menor densidade demográfica na área sobre o chapadão que se estende entre o rio das Velhas e o rio Tejuco, formada por latossolos álicos (em hachura), pouco férteis.

Assim, parece claro que, para uma população indígena sedentarizada e dependente de cultivos, o acesso a solos férteis era fundamental à localização dos seus sítios. Porém, a utilização de um sistema de cultivo de pousio arbustivo (Marcílio, 2000) levava as famílias a freqüentemente mudar a localização de seus sítios, de preferência em direção às áreas de mata virgem. Como os aldeamentos não cumpriam funções urbanas, sendo apenas habitats rurais concentrados, sua tendência, à proporção que as roças iam se distanciando deles, era de se despovoarem.

Um outro fator importante, que tendia a despovoar os aldeamentos, era a grande suscetibilidade das populações indígenas aos vírus e bactérias trazidos pelos colonizadores. Em São José de Mossâmedes, por exemplo, foram reduzidos os índios acroás, que tinham se rebelado no aldeamento do Duro, próximo a Natividade, em 1774 (CHAIm, 1983). Todos esses índios haviam morrido ou se dispersado até 1781, quando foram substituídos por javaés e carajás, que também se extinguiram até o início do século XIX. Finalmente, nos primeiros anos daquele século, Mossâmedes recebeu os caiapós trazidos da Aldeia Maria I. Estes, pouco antes da visita de Saint Hilaire, em 1819, haviam sofrido uma devastadora epidemia de sarampo, que exterminou mais de 80 índios (SAint Hilaire, 1975).

Nos aldeamentos da Farinha Podre, as epidemias também provocaram grande mortandade, principalmente nos seus primeiros tempos. Eschwege (1996) relatou que, em Santana, 50 anos antes de sua visita (portanto em 1766), havia ocorrido uma epidemia que vitimara um grande número de índios. Por causa disso, foram trazidos índios tapirapés, do rio Araguaia, para reforçar demograficamente a população do aldeamento. 

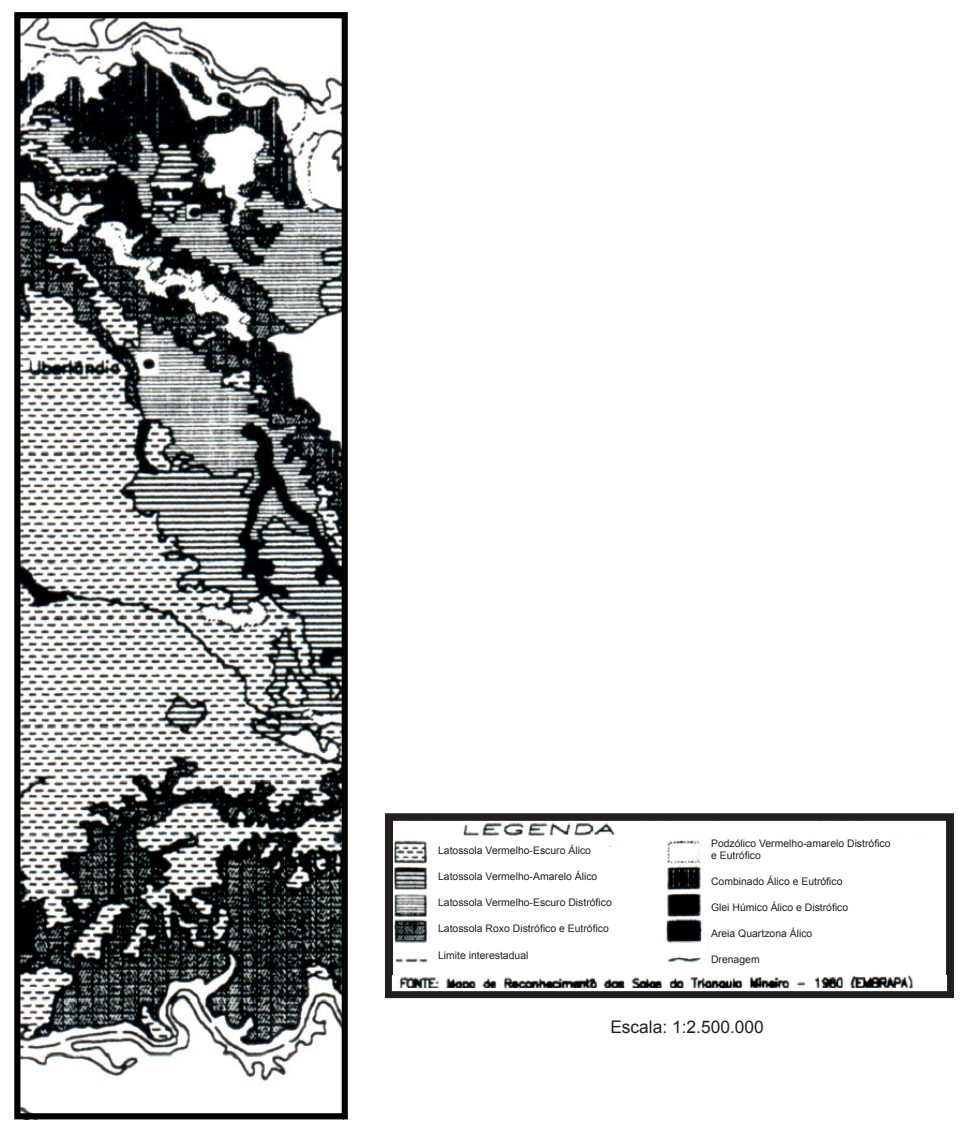

Escala: $1: 2.500 .000$

Figura 16: Mesorregião do Triângulo Mineiro: solos

Fonte: Siqueira e Rosa (1998).

Os deslocamentos forçados da população indígena foram um outro fator que alterou profundamente a demografia dos aldeamentos da região. Em 1775, uma leva de índios chacriabás foi trazida para Santana, vindos do Duro, após a já citada rebelião. Para que estes pudessem ser reduzidos, os índios que ocupavam anteriormente o aldeamento foram deslocados para o Lanhoso (CASAL, 1976). Em 1809, homens em idade militar foram transferidos em massa do Rio das Pedras para Nova Beira (Ilha do Bananal), para uma guerra contra os xavantes (Saint Hilaire, 1975, Chaim, 1983). A maioria 
deles morreu em combate, e ainda em 1816, Eschwege observara, em sua passagem por Rio das Pedras:

Estranhei a ausência de jovens de 14 a 20 anos. Indagando o motivo, foi-me dito que, 20 anos atrás, a maioria dos homens havia sido enviada contra os índios do Araguaia, tendo retornado apenas um pequeno número deles (EsCHWEGE, 1996, p. 118).

Pudemos reconstituir uma pequena série de dados demográficos de alguns núcleos indígenas, entre 1816 e 1823, graças aos dados coligidos por Saint Hilaire (1975, p. 154), Eschwege (1996, p. 126-127) e do tenente Francisco Inocêncio de Miranda (BARBosA, 1995, p. 39, 51, 128, 185, 251), que mostramos na tabela 1. Dela, excluímos os aldeamentos de Rio das Pedras, Santana e Uberaba, pois já nessa época recebiam intensa imigração lusobrasileira. Podemos perceber um aumento das populações de Estiva, Piçarrão e Boa Vista, enquanto houve decréscimo de Lanhoso e estagnação de Baixa. Baixa e Lanhoso, com tendência à estagnação e decréscimo populacional,

\begin{tabular}{l|c|c|c}
\hline \multicolumn{1}{c|}{ Aldeamento } & 1816 & 1821 & 1823 \\
\hline Estiva & 47 & 74 & 84 \\
\hline Pissarrão & 30 & 42 & 44 \\
\hline Boa Vista & 15 & 55 & 66 \\
\hline Lanhoso & 27 & 30 & 21 \\
\hline Baixa & 14 & - & 20 \\
\hline
\end{tabular}

Tabela 1 : população dos aldeamentos do Sertão da Farinha Podre de 1816 a 1823 Fonte: Eschwege (1996), Saint Hilaire (1975), Barbosa (1995).

situavam-se ao sul do rio das Velhas, no trecho de terras aldeanas entre esse rio e o Grande. Os demais, que mostravam um pequeno crescimento, situavam-se entre o rio das Velhas e o Paranaíba. O mapa da figura 16, que vimos anteriormente, expõe uma diferença significativa de densidade demográfica indígena, entre o norte e o sul do rio das Velhas, em 1821: ao norte, habitavam 637 índios, ou 0,51 por quilômetro quadrado de terras aldeanas; ao sul, estavam 234 índios, ou 0,10 por quilômetro quadrado (EsCHWEGE, 1996). 
Menores densidades de população indígena, tendência de decréscimo populacional: esses números refletem um processo que já havia se iniciado então, que era a espoliação de terras indígenas por colonos ao sul do rio das Velhas, no termo da freguesia de Uberaba. Liderados pelo sargento-mor Antônio Eustáquio Silva Oliveira, os colonos geralistas, que emigravam em massa vindos da região central da província de Minas Gerais, em poucos anos, exterminaram e expulsaram os índios da faixa aldeana. Anos depois, o mesmo aconteceria na faixa ao norte do rio das Velhas, no termo da vila de Araxá. Veremos esse processo com mais detalhes no capítulo que se segue. 